\title{
Hydrogels-Assisted Cell Engraftment for Repairing the Stroke-Damaged Brain: Chimera or Reality
}

\author{
Daniel González-Nieto 1,2,3,* Laura Fernández-García ${ }^{1}$, José Pérez-Rigueiro 1,3,4 , \\ Gustavo V. Guinea 1,3,4 (iD) and Fivos Panetsos 5,6 ii \\ 1 Center for Biomedical Technology, Universidad Politécnica de Madrid, 28040 Madrid, Spain; \\ laura.fernandezg@ctb.upm.es (L.F.-G.); jose.perez@ctb.upm.es (J.P.-R.); \\ gustavovictor.guinea@ctb.upm.es (G.V.G.) \\ 2 Departamento de Tecnología Fotónica y Bioingeniería, ETSI Telecomunicaciones, \\ Universidad Politécnica de Madrid, 28040 Madrid, Spain \\ 3 Biomedical Research Networking Center in Bioengineering Biomaterials and Nanomedicine (CIBER-BBN), \\ 28040 Madrid, Spain \\ 4 Departamento de Ciencia de Materiales, ETSI Caminos, Canales y Puertos, \\ Universidad Politécnica de Madrid 28040 Madrid, Spain \\ 5 Neurocomputing and Neurorobotics Research Group: Faculty of Biology and Faculty of Optics, \\ Universidad Complutense de Madrid, 28040 Madrid, Spain; fivos@ucm.es \\ 6 Instituto de Investigación Sanitaria, Hospital Clínico San Carlos Madrid, IdISSC, 28040 Madrid, Spain \\ * Correspondence: daniel.gonzalez@ctb.upm.es; Tel.: +34-913364653
}

Received: 20 December 2017; Accepted: 11 February 2018; Published: 13 February 2018

\begin{abstract}
The use of advanced biomaterials as a structural and functional support for stem cells-based therapeutic implants has boosted the development of tissue engineering applications in multiple clinical fields. In relation to neurological disorders, we are still far from the clinical reality of restoring normal brain function in neurodegenerative diseases and cerebrovascular disorders. Hydrogel polymers show unique mechanical stiffness properties in the range of living soft tissues such as nervous tissue. Furthermore, the use of these polymers drastically enhances the engraftment of stem cells as well as their capacity to produce and deliver neuroprotective and neuroregenerative factors in the host tissue. Along this article, we review past and current trends in experimental and translational research to understand the opportunities, benefits, and types of tentative hydrogel-based applications for the treatment of cerebral disorders. Although the use of hydrogels for brain disorders has been restricted to the experimental area, the current level of knowledge anticipates an intense development of this field to reach clinics in forthcoming years.
\end{abstract}

Keywords: biomaterials; hydrogels; stem cells; stroke; brain repair

\section{Introduction}

In recent decades, considerable progress has been made in the development of experimental therapies to treat different brain disorders. Among the different approaches examined, cell therapy has been configured as a viable option for restoring the damaged brain. Tissue recovery after damage has been associated with the mobilization and integration of new cerebral cells derived from exogenous sources. Alternatively, endogenous brain repair mechanisms may also be stimulated by the transplantation of different cell populations with the ability to secrete factors that mobilize endogenous neurogenesis. Cell transplantation through a systemic intravascular route has been regularly tested in animal models and brain injury patients. Intra-venous and intra-arterial administrations are considered relatively feasible to perform and are less invasive than cerebral implantation. However, the systemic route is handicapped by the inefficient mobilization of therapeutic cells from the blood 
towards the brain tissue given that most cells are retained in the pulmonary capillaries, spleen, liver, and kidneys [1,2], therefore limiting the number of cells able to reach the brain by crossing the blood-brain barrier which separates the circulatory system from the brain tissue. Despite its higher invasiveness, cerebral implantation is the most promising strategy because of the possibility of grafting a greater number of therapeutic cells in the area of interest, which might be restricted to or near the area of the lesion [3-8]. The relevance of this approach has been supported in later years by the progressive expansion of the number of clinical trials performing intracerebral cell implants in patients with cerebral damage using different populations of stem cells and progenitors of embryonic, hematopoietic, and mesenchymal sources.

However, even the cerebral route is not free of difficulties. Among them, we should mention the reduced temporality of the graft due to the poor survival ratio of the cells as well as their dispersion towards regions far away from the area of interest, thus diluting any therapeutic effect. It is assumed that in response to injury the brain tissue is converted into a hostile microenvironment not only for the brain itself, but also for the grafting of different cell populations that generally do not survive beyond a few weeks after implantation $[5,6,8]$. The lack of survival factors combined with cell death signals from reactive astrocytes, microglia and peripheral leukocytes not only contribute to damage the still alive brain tissue in perilesional areas but most likely also constitute the main causes for poor cell engraftment.

In regenerative neuroscience, the combined implantation of cells and different biomaterials to increase the viability of cellular grafts constitutes a very promising approach in full expansion [9]. In this context hydrogels rise as a powerful and versatile group of architectonic elements for cell encapsulation and brain reconstruction due to their special chemical and physical structures with stiffness modules in the range of the soft tissues such as the brain. Given the increasing variety of applications and experimental models for the development of biomaterials-based stem cell therapies for neurological disorders, this review focuses on current knowledge on the use of hydrogels-based cell therapy for ischemic brain injury (ischemic stroke), which represents the most frequent type of disabling neurological pathology [10]. An additional objective is to provide a global view of the biomedical problems as well as of the past and current trends in the related experimental and translational research. Finally, we aim at highlighting the opportunities, type of applications and possible benefits of hydrogels-based cellular therapies for ischemic brain injuries. For a deeper understanding of the application of hydrogels and therapeutic cells in the treatment of other less frequent but not less important neurological disorders, several comprehensive reviews have been included in the Reference Section [11-14].

\section{Clinical Scenario and Challenges to Solve}

Cerebrovascular diseases encompass a set of syndromes of different etiology and severity that lead to transient or permanent disorders of brain function. Pathologically, cerebrovascular diseases may be a consequence of: (i) alterations in cerebral blood flow; (ii) disturbances in blood circulation that modify blood flow and pressure; and (iii) disorders of cardiac function. Stroke represents a sudden onset of cerebrovascular disease and occurs in most cases through a vascular obstructive process (ischemic; $\sim 85 \%$ of stroke patients) or by the rupture of one or more brain blood vessels and extravasation of blood (effusion) into the extravascular space (hemorrhagic; $15 \%$ of stroke patients), both leading to a reduction or total abolition of blood supply to the brain. Epidemiologically, stroke is a leading cause of adult disability and cognitive impairment and is the second-leading global cause of death behind ischemic heart disease [10,15]. It is estimated that after stroke a substantial proportion of patients $(25-50 \%)$ remain dependent for at least one daily task up to six months after injury [16] producing incalculable personal, family, and social costs worldwide. The main risk factors for stroke include high blood pressure, ischemic heart disease, diabetes mellitus, disorders of heart rhythm, high blood cholesterol and lipids, smoking, physical inactivity, diet and weight, family history, and genetic background. Due to the progressive increase in life expectancy, it is assumed that in the next few 
decades there will be a parallel increase in the number of stroke cases (confirmed by the fact that stroke incidence has increased by up to $20 \%$ in the last few years $[15,17])$ increasing the susceptibility of suffering this vascular affectation at an even earlier age [18].

Mitigation of stroke-originated brain damages strongly depends on the recognition of signs and symptoms in the hospital emergency area and the consequent rapidity of medical intervention. Hemiparesis, loss of sensation, impaired speech, vertigo, and gait disturbances represent the initial clinical signs $[19,20]$. In ischemic stroke, the early reestablishment of blood flow in the obstructed vessel is a strong determinant for the clinical evolution of the patient. The intravenous injection of the tissue plasminogen activator (tPA) alone or in combination with surgical procedures such as endovascular thrombectomy for the recanalization of the occluded vessel are currently the main therapeutic approaches for eliminating the obstructive clot $[19,21-23]$. However, the percentage of stroke patients that can get benefit from these two treatments is extremely low. Due to the short therapeutic window (3.0-4.5 h after the onset of the attack) and the risk of complications, only $6 \%$ of the affected people are eligible for these treatments. In addition, tPA is effective in less than $10 \%$ of the treated cases, reducing the possible beneficiaries to less than $0.6 \%$ of the affected population. Endovascular thrombectomy is even less effective, being also very limited the number of teams specialized in this type of intervention.

Patients who survive a stroke and do not receive adequate treatment within this narrow therapeutic window or when its reception is ineffective often show disabilities with different degrees of affectation [24]. For these patients, no therapies are currently available for the repair of the damaged brain or for the promotion of a satisfactory degree of functional recovery [25]. Physical and/or cognitive rehabilitation, transcranial magnetic (TMS) or direct-current (tDCS) stimulation may lead to a functional improvement in a reduced number of patients during the chronic phase of disease. There are contradictory results among different groups on the efficacy of these types of approaches most likely related to the heterogeneity and low number of patients participating in the clinical trials and the lack of consensus in the methodologies used [26-29]. Instead of reconstructing the neural tissue, neuro-rehabilitation and training strategies promote the emergence of new circuitry in non-injured areas surrounding (perilesional) the damaged tissue. This perilesional tissue may take control of specific functions that were lost and initially dependent of the injured areas ("vicarious" function), as has been demonstrated previously in pioneering studies with monkeys and humans [30,31]. However, and despite contradictions [32], neuro-rehabilitation and training strategies may result very useful for the functional improvement of stroke patients particularly when applied in synergy with other promising therapeutic alternatives, as for example biomaterials-based therapy.

Cell therapy has been proposed as a strong and convenient strategy for the reconstruction of the damaged brain tissue or guide cerebral plasticity in perilesional areas enhancing functional recovery. Transplanted cells should modulate recovery mechanisms similar to those acting in spontaneously healing or rehabilitation improvements. The first objective of cell therapy is to provide a source of transplanted exogenous cells that can differentiate into the main components of nervous tissue (neurons, astrocytes, oligodendrocytes, and vascular endothelial cells). Additionally, transplanted cells should stimulate endogenous self-repairing mechanisms and produce biomolecules to promote neurogenesis and angiogenesis. A variety of stem cells, progenitors and differentiated cells have been engrafted in different models of brain damage. Since the first studies using cells from neural or hematopoietic origin to promote recovery in ischemic animals [33-37], in the last two decades, we have witnessed a growing number of clinical trials with different types of cell populations transplanted either systemically or intracerebrally [38-47]. In the next section, we discuss the timeline for stroke treatment after two decades of experimental and clinical research in cell-based therapies and we introduce elements for reasoning about the use of hydrogels based on different materials as a support for cell engraftment and function. 


\section{Therapeutic Intervention after Stroke: What Have Two Decades of Cell Therapy Research Taught Us?}

The use of cell therapies for the treatment of human diseases dates back to the 1950s, specifically in the area of hemopathies. In those years, two independent groups reported how the intravenous administration of hematopoietic stem cells and progenitors from spleen or bone marrow favored the hematopoietic regeneration of mice previously subjected to myeloablation by lethal irradiation $[48,49]$. Thomas et al. were pioneers in performing the first cell-based therapy by transplanting bone marrow in six human patients previously mieloablated with irradiation or chemotherapy to treat leukemia and multiple myeloma [50]. Since then, cell therapy has been configured as a plausible strategy for tissue and organ regeneration in other human disorders, mostly by using undifferentiated cells with characteristic self-renewal and potency properties, the so-called stem cells (SCs). In addition to bone marrow transplantation, which probably constitutes one of the most relevant cell-based therapies with proven efficacy in the treatment of malignant disorders related to hematopoietic dysfunctions, cell transplantation has been approved for other diseases such as the use of limbic stem cells (ISCs) to regenerate the cornea after ocular burns [51] or the use of mesenchymal stem cells (mSCs) to treat perianal fistulas in Crohn's Disease [52]. Very recently transgenic SCs have been used clinically to produce skin implants for junctional epidermolysis bullosa disease [53]. The number of clinical studies has grown exponentially. For example in the case of mSCs more than 300 clinical trials have been carried out in the last years to evaluate the repair potential of this cell population in bone, cartilage, heart, lung, liver, kidney, autoimmune, gastrointestinal and neurological disorders [54]. However, despite great advances in preclinical and clinical environments, the market for cell-regenerative medicine is still in its infancy and no more than 10 marketing licenses have been granted in the European Union to treat diseases not related with cerebral disorders [55]. Another example of the slow transition to the regular use of SCs in patients is illustrated by the first approval by the US Food and Drug Administration (FDA) of a cell-based gene therapy to treat lymphoblastic leukemia on August 2017 [56].

In the area of cerebral disorders and specifically in stroke, during the last two decades, numerous studies with animals have validated the efficiency of different cell populations (mainly stem cells and progenitors of diverse tissue sources) in promoting functional recovery after brain injury. In addition, considerable progress has been made in the study of the molecular and cellular substrates responsible for this recovery. Knowledge obtained in last few years about the action mechanisms of the different SCs as well as about their therapeutic limitations moved this field into a new scenario, the combined implantation of SCs with different biomaterials of natural or artificial origin. Generally, different stem cells and progenitors (SCs/P) are capable to differentiate into progressively more mature cell phenotypes (neurons, astrocytes, and oligodendrocytes) as well as to secrete different trophic factors [57,58]. Both abilities can be exploited therapeutically: (i) to protect neurons from a hypoxic hostile environment and decrease the post-ischemia inflammatory response [59,60]; (ii) to favor the replacement (restitution) of damaged neurons with new neural cells creating new circuitry in the injured areas [8,61,62]; and (iii) to enhance tissue remodeling mechanisms in perilesional regions of the damaged brain. This last one is especially relevant for functional recovery after cerebral ischemia [3].

When a cerebral infarction occurs the injured area is anatomically and functionally categorized in a central nucleus where blood flow has been totally interrupted and brain tissue evolves towards infarcted condition (infarct core) and a perilesional area where the blood flow has be reduced but not abolished containing structurally intact but functionally inactive neural networks (ischemic penumbra) [63]. If the reduced blood flow persists, penumbra is irreversibly damaged while reperfusion with an adequate blood flow speeds down the ischemic process. After the damaged area has been established the perilesional tissue might undergo functional modifications (plasticity) to sustain post-stroke functional recovery as has been reported in humans subjects and animal models [64]. 


\subsection{Stem Cells for Neuroprotection and Repair of the Injured Brain}

Over the last two decades, different type of cells (mostly multi- and pluripotent stem cells) have been used as therapeutic tools to enhance nervous tissue regeneration and brain plasticity phenomena (Figure 1). After the initial injury different SCs might neuroprotect the brain by the reduction in apoptosis and diminishing of post-ischemic inflammatory response that commonly exacerbates the brain damage propagating injury towards healthy tissue areas. The transplanted SCs might also stimulate the mobilization and production of endogenous neural SCs and progenitors in the subventricular zone (SVZ) and hippocampus (stimulation of endogenous neurogenesis) or produce themselves different neural lineages, for example when exogenous nSCs are cerebrally implanted. Exogenous SCs- or endogenous SCs-derived newborn neural cells (NNcells) might replace damaged cells creating new circuitry in the infarcted tissue or might be integrated in pre-existing neural networks in the perilesional tissue. Apart from NNcells integration, other forms of functional plasticity supported by the paracrine action of SCs (secretion of factors) occur at structural level, including the formation of new synapses (synaptogenesis), dendritic branching and growth and axonal sprouting favoring neuronal connectivity in the perilesional tissue, which have strong potential for plasticity after brain damage. In addition, different SCs may stimulate angiogenesis creating an optimal vascular network microenvironment for cell replacement, neural integration and plasticity. Many of these mechanisms can be favored by engineered polymers which provide structural and functional support for the engrafted stem cells.

Among the various types of stem cells, neural stem cells (nSCs) and neural precursors (nPCs) were initially established as the ideal cell populations for the repair of central nervous system. During embryonic development, neurogenesis through natural and pre-existing nSCs and nPCs principally occurs in two main brain regions: the subventricular zone (SVZ) and the ventral and lateral ganglionic eminences (VGE and LGE). The first region (SVZ) is the origin of the largest population of neocortical neurons while the ganglionic eminences give rise to the neurons of the basal ganglia and the neocortical interneurons [65]. In contrast, in the adult brain the main neurogenic niches are restricted to the ventricular/subventricular region as well as to the subgranular region (SGZ) of the dentate gyrus of the hippocampus [66]. Adult neurogenesis is regulated over several stages including maintenance and self-renewal of nSCs [67], proliferation and migration of nPCs, as wells as survival, maturation, and cellular integration in already established circuits or in ex novo built neural networks. After brain injury, endogenous nPCs migrate to the zones of damage $[68,69]$ following the chemoattracting signals secreted by astrocytes, microglia, and vascular endothelial cells [66]. However, the number, recruitment and integration of neural cells are insufficient for the reestablishment of the neurological functions. Thus, although present, the endogenous neurogenesis is extremely inefficient which explains the lack of substantial post-stroke spontaneous recovery in humans and animals.

The implantation of nSCs has been considered a therapeutic option to favor the production and integration of terminal neural cells in either the core or the perilesional regions [70-72]. Additionally, donor nSCs stimulate endogenous neurogenesis [72,73] as well as angiogenesis [74]. Part of nSCs regenerative effects can be explained by their secretoma activity including the release of different proteins such as vascular endothelial growth factor (VEGF), brain derived neurotrophic factor (BDNF), nerve growth factor (NGF), and tumor necrosis factor alpha (TNF- $\alpha$ ) among others [75,76]. To provide some representative examples of the therapeutic use of nSCs, in one study the implantation of human nSCs increased axonal transport, dendritic ramifications and axonal growth and propagation, all of these known to be mechanisms that contribute to the increase of neuronal plasticity, promoting the functional recovery of rats with focal ischemia [3]. 

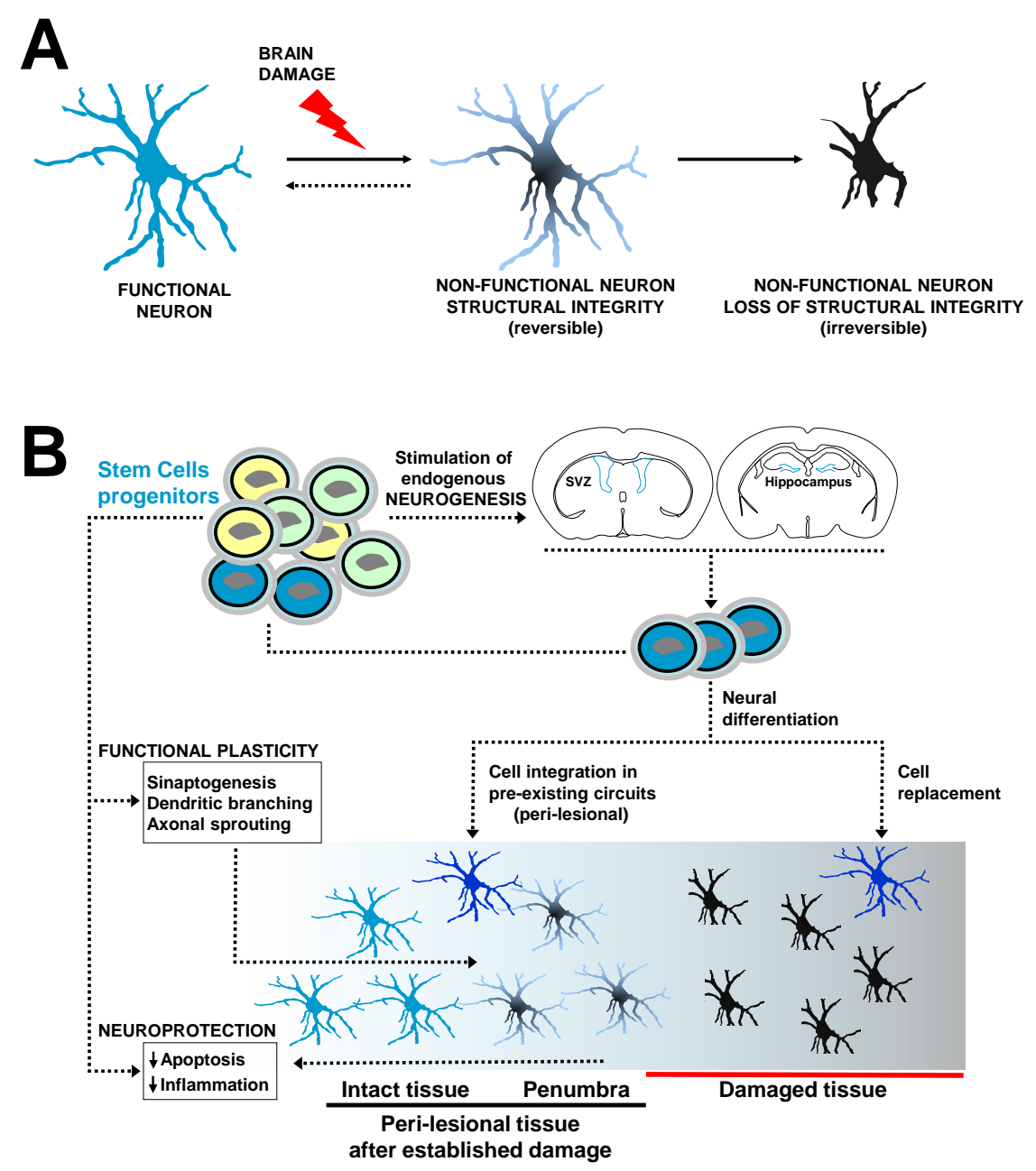

Figure 1. Stem cell mechanisms underlying recovery after cerebral damage. (A) After ischemic stroke, functional neurons (pre-ischemic; blue, left) go through different states including a reversible non-functional state called penumbra (black-blue, middle). If lack of blood flow persists, then irreversible neuronal death occurs (black, right). (B) Several mechanisms have been proposed to explain the therapeutic effects of different stem cells (SCs). (1) Neuroprotective mechanisms: At this level, the different SCs exert their effects by the reduction in apoptosis and diminishing of post-ischemic inflammatory response (immunomodulation). (2) Neuro-restitution and neuro-plasticity: The transplanted SCs might stimulate mobilization and production of endogenous neural SCs (stimulation of endogenous neurogenesis) or produce themselves different neural lineages, for example when exogenous nSCs are cerebrally implanted. All these neuro-therapeutic mechanisms induced by SCs might be drastically enhanced by engineered polymers which provide structural support for increasing survival and function of engrafted stem cells.

In stroke mice, the intracerebral co-transplantation of human nSCs and the protease 3K3A-APC to stimulate the in vivo proliferation of transplanted nSCs reestablished the neural circuitry favoring post-stroke functional recovery [8]. However, when the nSCs were injected alone (without the 3K3A-APC protease), no significant recovery was observed, an effect that was in part related to a dramatic decrease in the injected nSCs content from two to three weeks after transplantation. This is a regular observation, since in many studies, and independently of the route of administration, the limited therapeutic effect of the transplanted SCs on post-stroke recovery may be ascribed with the poor engraftment and severe reduction of the transplanted cellular content in a hostile microenvironment as is the damaged brain $[6,8,25,77]$. As discussed later, a main role of biomaterials used for the integration of donor cells is to create an adequate structural microenvironment to favor 
the survival, retention, and cross-talk of the implanted cells with the host nervous tissue. Although nSCs-based regenerative therapies are very promising, the most significant disadvantages for their use in clinics are their scarce availability and difficulty of ex vivo expansion as well as the immunogenicity of allogenic transplants [78].

Embryonic stem cells (eSCs) constitute an alternative type of SCs that have been commonly used in a wide variety of studies. They are pluripotent cells capable of self-renewing and differentiating into any cellular phenotype of the organism including the neural lineage. The ability of eSCs to promote post-ischemic functional recovery has been demonstrated in several studies [79,80]. However the ethical limitations derived from its isolation from embryonic tissue [81] as well as the malignant transformation of this cellular phenotype and its tendency to frequently form teratomas in vivo [82] makes them less suitable for clinical applications.

Mesenchymal stem cells (mSCs), bone marrow mononuclear cells (BMmCs), and induced pluripotent stem cells (iPSCs) represent an alternative to nSCs and eSCs since they can be isolated, generated and expanded with no excessive difficulty. These cell populations have shown neuroprotective and neuro-regenerative effects in different animal models. They can be isolated or generated from the patients themselves therefore allowing autologous transplantation and avoiding graft rejection. Among the potential benefits of mSCs, iPSCs, and BMmCs it is worth mentioning the modulation of the brain tissue microenvironment through the secretion of several growth factors that regulate the immune response, limit astrogliosis and microgliosis, stimulate endogenous neurogenesis and angiogenesis or reduce apoptosis by decreasing the oxidative stress [83-85].

The iPSCs hold many of the functional properties found in eSCs, exhibiting similar morphology, the endogenous expression of pluripotency genes and their ability to self-renew or differentiate into progenitors, precursors, and mature cells of different germinal origin including neural cells [86]. Differentiated somatic cells can be reprogrammed to pluripotency (iPSCs) by treatment with defined factors. Several groups have been able to induce pluripotency easily and non-invasively from different somatic cells including fibroblasts, bone marrow, adipose tissue, and peripheral leukocytes [87-89]. Chen et al. found in a rat focal ischemia model that after the combined subdural transplantation of iPSCs and fibrin glue, there was a significant reduction in the infarct volume and a greater functional recovery in the animals examined with the rotarod test [90]. It has also been reported in infarcted rats that the intracerebral transplantation of iPSCs in both the affected and non-affected hemispheres induced their migration to the damaged area and subsequent differentiation into neural cells that enhanced post-stroke sensorimotor function recovery [91,92]. However, results are not conclusive since in other studies the iPSCs did not produce a substantial recovery of infarcted animals and the incidence of tumorigenesis was relatively elevated [93]. Thus, some limitations inherent to their genotype of iPSCs should be surpassed such as the possible mutations in cancer-related genes, aneuploidy and DNA aberrant methylation causing genomic instability, which have been associated with the formation of tumors and therefore incompatible with their clinical translation [93-95].

The BMmCs constitute a heterogeneous group of mature hematopoietic cells (B cells, T cells, and monocytes) and a small proportion of stem cells and hematopoietic progenitors, which together with stem cells and progenitors of mesenchymal origin (mSCs) represent a promising approach for the treatment of cerebrovascular disorders. BMmCs increase neurogenesis $[62,96]$ and cerebral plasticity [97] as well as favor blood flow to the damaged tissue by increasing angiogenesis, thus creating a microenvironment suitable for the migration and integration of neural cells and the replacement of lost tissue promoting functional recovery in infarcted animals.

\subsection{Mesenchymal Stem Cells}

mSCs are by far one of the most commonly employed cell populations. mSCs constitute a heterogeneous non-hematopoietic cell population which were first characterized by Friedenstein et al. in 1970 [98]. Although these cells can be isolated from different tissues including fat, umbilical cord and bone, it is in the bone marrow where they are present in a higher content [99], providing signaling 
for hematopoietic stem cell survival and function $[100,101]$. The special functional characteristics of mSCs and their strong potential for the treatment of cerebral disorders including stroke made them one of the better studied cell populations [35-37,102-109]. The wide variety of studies came through a significant advance in the knowledge of the neuroprotective and neurorepair mechanisms regulated by the paracrine activity of the mSCs. Pioneer studies reported mSCs are able to differentiate into neural phenotypes $[110,111]$ but later studies have discredited the direct transdifferentiation of mSCs into neural lineages [112]. Current consensus is that most mSCs therapeutic effects are due to the secretome activity of these cells, which, independently of the administration route (cerebral, nasal, and intra-arterial/venous), is able to modulate the main neuroprotection mechanisms, i.e., post-stroke immunoresponse, inflammation and apoptosis [113].

mSCs may reduce inflammatory response and apoptosis by decreasing the levels of pro-inflammatory molecules such as interleukins IL-1 $\beta$ and IL-6A, or TNF- $\alpha$ [114-116]. Immunomodulation of the damaged brain is important to reduce the inflammatory response minimizing injury and promoting recovery [117]. Inhibition of inflammation has been related to the increased levels of neurogenesis [118]. mSCs participate in regulating the M1/M2 activation balance by biasing microglia differentiation towards the anti-inflammatory M2 state for resolution of inflammation and tissue repair in detriment of the pro-inflammatory M1 phenotype $[119,120]$ and mSCs implantation has also been correlated with a reduced astrogliosis [121]. mSCs secretome also promotes angiogenesis, neurogenesis, and sinaptogenesis which in turn facilitate post-stroke brain repair and plasticity [122]. Angiogenesis in the perilesional tissue plays a crucial role in the survival and regeneration (restitution) of the damaged tissue. Intravenous administration of mSCs increases VEGF levels in rat ischemic tissue and provokes a strong development of microvasculature in the perilesional cortex of the infarcted hemisphere [102,123]. Angiogenesis as well as neurogenesis might be promoted by factors released by mSCs, including NGF, BDNF, VEGF, Glial-cell-derived-neurotrophic factor (GDNF), placental growth factor (PFG), or stromal-derived-factor (SDF-1) [2,6,102,124,125]. After ischemic damage, immature Doublecortine (DCX) positive neurons migrate from their neurogenic niches (SVZ) to areas of the perilesional tissue, deviating from their natural route to the olfactory bulb $[126,127]$. After thrombotic infarction in mice, the intracerebral transplantation of mSCs in the striatum was associated with increasing neurogenesis determined by an increment of cell proliferation and the content of $\mathrm{DCX}^{+}$cells in areas surrounding the infarct core as well as with vascularization in the damaged area accompanied by a reduction of glial scar [6]. Finally, mSCs favor neuronal plasticity by increasing the number of synapses in both damaged and intact hemispheres in models of unilateral infarctions [128,129]. Axonal sprouting and myelin formation are essential for the reconstruction of the damaged neural circuits and could also be modulated by the implantation of mSCs in the brain [130].

Most of the above mentioned neurotherapeutic mechanisms are related to the factors released by the mSCs, which might have a certain parallelism with the secretome activity present in other types of stem cells with known neuroprotective and neuroregenerative potential. While many of these factors can be secreted by exocytosis which constitutes a main mechanism for releasing extracellular proteins or neurotransmitters in neurons, recent studies suggest that part of the paracrine action of mSCs may be accomplished by cell-derived vesicles also called exosomes that could transport mRNAs, miRNAs and proteins with tissue repairing potential [131,132]. In vitro studies have shown that exosomes stimulate the axonal growth of cortical neurons [133] as well as favor angiogenesis. Intravenous administration of mSCs in infarcted rats enhanced functional recovery through the microRNA 133b, which is present in exosomes released from mSCs [134]. In this study MiR-133b promoted axonal plasticity and neurite remodeling in the perilesional cortex [134].

\subsection{Optimal Time Window and Best Administration Route}

Although stem cell implantation in experimental models of stroke has been performed even several weeks after cerebral damage [61,135] significant post-treatment recovery is usually observed with cell implantation within $24 \mathrm{~h}$ to a few days after injury. This might be explained by the existence of 
a putative optimal intervention window for promoting recovery, neuro-restitution, and neuro-plasticity after brain injury consensually restricted to the first post-stroke days $[5,6,8]$. For example, physical rehabilitation is powerful when starts in the first 1-2 weeks after brain damage while no significant post-stroke improvement has been observed when started several weeks post-stroke [136]. However, many stroke patients continue improving for years after brain injury bringing to debate the limits of such temporal window. With respect to the SCs, there is no consensus regarding the best temporal point for their implantation [137].

The optimal route for cell implantation has still to be defined, although cerebral administration reports better benefits than that of intra-venous and intra-arterial infusion [137]. Surprisingly, the number of studies comparing the efficacy of different routes of administration using the same cellular phenotype and brain damage model is quite limited. In terms of therapeutic efficacy intra-arterial administration is comparable to intra-arterial infusion [138] and different types of SCs have been employed in models of cerebral infarction where, in many cases, functional improvement has been observed $[102,104,114,138]$. Although both routes of administration are relatively safe and less invasive than cerebral implantation, one main limitation of systemic intravascular transplantation is the reduced migration of the implanted cells towards the brain, which might be trapped in the pulmonary capillaries, spleen, kidney, or liver, thus diminishing its therapeutic effect [1]. In addition, systemic administration is not free of complications and risks, for example because of the formation of pulmonary and brain microembolisms that are mostly related to cell size and concentration as well as to infusion velocity $[1,139,140]$. In contrast, intranasal delivery of SCs is safe, feasible, and poorly invasive [141]. Cells administered via this route must pass across the intranasal mucous epithelium towards the brain tissue until they reach the area where therapeutic effect is needed [142]. However, the mucociliary tissue represents a barrier for particles and microorganisms where cells might get trapped, which obliges to increase the cellular doses to achieve a measurable therapeutic effect [142]. Up to date no clinical trials have been performed with this delivery route and it is unknown if the large migratory distance between mucociliary tissue and brain in humans represents a serious limitation [1].

Cerebral implants are more invasive than other transplantation routes. In general, the implantation of cells in the rodent brain has not been translated into important side effects. However, the human brain is extremely sensible to surgical manipulation and minor damages could create profound functional deficits beyond previous stroke-originated dysfunctions [143]. However, cerebral implants represent the most efficient approaches to promote post-stroke functional recovery $[6,8,144,145]$. They provide precision in terms of graft location as well as control of the number of the implanted cells. Furthermore, cerebral implants circumvent the blood-brain-barrier (BBB) which constitutes the stronger limitation for the transplanted cells when they are infused systemically or intranasally. The cerebral implants are also of relevance when hydrogels are used to assist the function of therapeutic cells. In a low percentage of patients SCs implantation has been related with important side effects such as focal hemorrhage, chronic subdural hematomes, seizures and psychomotor exacerbation $[1,41,47,146]$. However, cerebral implants might be justified by weighing the benefits of quality of life of the individual patient against the infrequent potentially life-threatening side effects. When considering the cerebral route there is also a lack of consensus regarding the best place for cell implantation to achieve a better recovery. Few cells survive beyond two or three weeks after cerebral transplantation $[5,6,8,77,78]$, but the rate of survival is higher when SCs transplantation is performed in perilesional areas or far away from the cavity lesion $[5,8]$. After brain injury, the inflammatory response creates a hostile environment deleterious for both, the brain itself and the engrafted cells, making graft location critical for the survival of the implanted cells [5]. Short-lasting SCs survival inevitably leads to a non-durable therapeutic effect (cell differentiation and factors secretion). Similarly, if structural and functional changes of perilesional tissue are essential for plasticity and recovery, then SCs transplantation in these areas could be counterproductive. To overcome some of these obstacles, hydrogels-integrated SCs and factors have been implanted in the stroke cavity observing behavioral improvement in the animals treated despite a priori inhospitability of the infarcted area $[144,147]$ 
or have been applied epi-cortically (to the brain cortical surface) in a theoretically less invasive approach [7].

\subsection{Clinical Scenario: Where Are We Now?}

The safety and tolerability of the implantation of SCs in patients with cerebral damage has been widely demonstrated for different types of SCs and for all administrative routes [38-47] although some adverse effects have been observed in a minor fraction of treated patients [41,47]. Results about the neuro-therapeutic efficacy of the SCs are not conclusive, possibly because of the small number of patients included in the studies and the variability of the location of the stroke. In one of the first clinical trials, Bang et al., proved both the safety and efficacy of the intravenous transplantation of autologous mSCs in stroke-injured patients. They reported a reduction of the neurological deficits in the large majority of the treated patients [38] but their conclusions raised concerns because of the reduced number of subjects and the lack of adequate controls [148]. Subsequent studies have demonstrated the safety and efficacy of the systemic administration of mSCs, here too, a reduction of post-stroke functional deficits was observed $[44,149]$. Recently, a comparison was made between the effect of intravenous injection of mSCs with respect to the combined co-transplantation of mSCs plus nSCs through the cerebellomedullary cistern [150]. After two-years follow-up, no serious adverse effects were observed (neurological infections, tumor formation) except for low fever ( $30 \%$ of patients) and temporary dizziness, and most patients showed clinical improvements [150]. However, the reduced number of patients (six subjects) limited the conclusions of the study. The safety and the therapeutic effects of systemic and intra-cerebral transplantation of BMmCs, nSCs, and mSCs have been corroborated by several other studies $[41,46,47,151,152]$. Collectively, there is a need of clinical trials involving a high number of patients, more homogenous and with better inclusion/exclusion criteria [153]. In addition, a greater number of pre-clinical studies are required to further investigate the neuro-therapeutic mechanisms of action of different SCs. The cellular and molecular substrates responsible for recovery are in general not well understood. In a few experimental studies, relevant mechanistic information for recovery has been obtained, which has been related to the production of nSC-derived newborn neurons and their functional integration with the host tissue [8], and structural changes (plasticity) related to axonal sprouting and dendritic branching of the host neurons after implantation with human neural progenitors and their secretome activity [3]. In contrast, the modest functional recovery observed in preclinical and clinical studies could originate from the cells implanted systemically and intra-nasally not migrating to the brain tissue with all the required efficacy [137]. In the case of cerebral transplantation poor recovery could be related to a progressive dispersion of the SCs outside the implanted area and to a higher mortality of the transplanted cells in the inflammatory post-ischemic brain tissue $[5,6,77,124,154]$. Poor engraftment of SCs into the brain is being tentatively resolved with different approaches, for example the combined implantation of SCs and factors that increase donor cell expansion [8] or the use of different biomaterials to assist cell survival and function [144], as we will discuss in the next section.

\section{Hydrogels-Assisted Cell Therapies for Brain Stroke}

The use of biomaterials to assist cell therapy after brain injury is merely restricted to the experimental arena, which raises important concerns on whether we are really seeding a reasoned technology for future use in patients, or if we are facing an unreachable scenario. Preclinical data have supported the efficacy of the co-transplantation of hydrogels and cells to repair the damaged brain $[135,144,155,156]$ and a growing number of clinical trials have demonstrated the feasibility and relative safety of cerebral implants with different SCs [39]. Thus, the available evidence envisages a horizon where different biomaterials, mostly in the form of hydrogels, could be useful in enhancing cellular engraftment to assist SCs therapeutic effects.

The concept of hydrogels for biomedical applications comes from the 1960s by using copolymers of glycolmethacrylates $[157,158]$ to design structures with adjustable water content ( $>90 \%$ water), 
inertness with cells and tissues and permeable to metabolites through pores with adaptable sizes depending on polymerization conditions and crosslinking density. Hydrogels have been employed for a variety of biomedical uses such as for mimicking extracellular matrix tumors for cancer, for the delivery of chemotherapy drugs [159], or for heart repair [160]. Hydrogel polymers swell in contact with aqueous solutions and show a high affinity for absorbing water molecules remaining in an insoluble three-dimensional network state. Hydrogel properties can be adjusted to modify the gelation time or even delay their degradation both in vitro and in vivo. Various comprehensive reviews regarding the manufacturing methods of hydrogels and control of their properties have been included in the Reference Section [161-163]. Due to their high content of water hydrogels are ideal for implants in soft tissues such as the brain, in applications that span from cell encapsulation, to the control of the release of cell-secreted factors, but also for the controlled delivery of therapeutic drugs and different molecules, or just as imageable biomaterials [164]. In addition, hydrogels provide architectural support in the damaged and perilesional nervous tissue favoring cell-to-cell interaction and neural networks connections. Accumulated experience indicates that the mechanical properties of hydrogels modulate neural adhesion, proliferation differentiation and function. For example, it has been reported that neuronal adhesion on polyacrylamide gels increased with increasing elastic modulus, but this variation in stiffness did not modify neurite length [165]. In another study, the survival of neural cell cultures was better in more compliant hydrogels with compressive modulus below $3.8 \mathrm{kPa}$ [166] or, more precisely, in the range of 0.1-1.0 $\mathrm{kPa}$ [167]. Stiffness can be modulated by changing the polymer concentration and the crosslinking density to achieve mechanical properties in the range of neural tissue [168-170]. In general, higher cross-linking densities and polymer concentrations lead to stiff hydrogels, while more compliant hydrogels are mostly obtained with fewer cross-links. The latter are supposed to be more adequate for brain applications [167]. Stiffness also decreases as a function of hydrogel degradation. It is generally assumed that matching the hydrogel mechanical properties with the brain stiffness is important to minimize contact stresses and to reduce the possible immune response. However, some controversy exists in the literature regarding the approximate stiffness of brain tissue, which probably is related with the analysis of mechanical properties in different anatomic regions, age and species used (human, primates, rodents) as well as with the testing methods (Table 1). For example, a mechanical stiffness of $\sim 50 \mathrm{kPa}$ has been determined in the mouse and rat brains by confined compression tests [170]. Alternatively, a brain tissue stiffness of $25 \mathrm{kPa}$ has been found in the mouse brain using magnetic resonance elastography [169]. Other groups have reported lower compressive modulus for the brain tissue which range $10.0 \mathrm{kPa}[166,171-173]$ to the lowest value of $0.3 \mathrm{kPa}$ measured for the elastic modulus of cerebellum [174]. In addition to polymer concentration and crosslinking density, the stiffness of hydrogels can be tuned by changing parameters such as the molecular weight of monomers, the molar ratio of donor/acceptor groups, the number of reactive groups (i.e., acrylates in photo-crosslinked hydrogels) or by varying the ionic concentration $[167,175]$.

Table 1. Mechanical properties of brain tissue and hydrogel polymers used for cell encapsulation in neurorestaurative therapies studies.

\begin{tabular}{cccc}
\hline Organ/tissue & Measured property & Measured value & References \\
\hline Brain (rat and mouse) & Elastic modulus (Compressive) & $\mathrm{E}=50 \mathrm{kPa}$ & {$[170]$} \\
\hline Brain (rat) & Shear storage modulus & $\mathrm{G}^{\prime}=0.33 \mathrm{kPa}$ & {$[171]$} \\
\hline Brain (rat) & Shear storage modulus & $\mathrm{G}^{\prime}=0.6 \mathrm{kPa}$ & {$[172]$} \\
\hline Brain (swine) & Elastic modulus & $\mathrm{E}=3.2 \mathrm{kPa}$ & {$[176]$} \\
\hline Brain (mouse) & Shear modulus & $\mathrm{E}=25 \mathrm{kPa}$ & {$[169]$} \\
\hline Brain (rat) & Bulk elastic modulus & $\mathrm{E}=5.5 \mathrm{kPa}$ & {$[173]$} \\
\hline Brain (rat) & Bulk elastic modulus & $\mathrm{E}=5.7 \mathrm{kPa}$ & {$[177]$} \\
\hline Cerebellum (rat) & Bulk elastic modulus & $\mathrm{E}=0.3-0.45 \mathrm{kPa}$ & {$[174]$} \\
\hline
\end{tabular}


Table 1. Cont.

\begin{tabular}{|c|c|c|c|}
\hline Biomaterial hydrogel & Measured property & Measured value & References \\
\hline HA & Bulk elastic modulus & $\mathrm{E}=7-8 \mathrm{kPa}$ & [177] \\
\hline HA & Shear Storage/Loss modulus & $\begin{aligned} \mathrm{G}^{\prime} & =0.33-0.84 \mathrm{kPa} \\
\mathrm{G}^{\prime \prime} & =0.001-0.01 \mathrm{kPa}\end{aligned}$ & [179] \\
\hline $\begin{array}{l}\text { HA with MPP } \\
\text { degradable }\end{array}$ & Shear Storage/Loss modulus & $\begin{aligned} \mathrm{G}^{\prime} & =0.33 \mathrm{kPa} \\
\mathrm{G}^{\prime \prime} & =0.0057 \mathrm{kPa}\end{aligned}$ & [180] \\
\hline $\begin{array}{l}\text { HA with MPP } \\
\text { nondegradable }\end{array}$ & Shear Storage/Loss modulus & $\begin{array}{c}\mathrm{G}^{\prime}=0.29 \mathrm{kPa} \\
\mathrm{G}^{\prime \prime}=0.0024 \mathrm{kPa}\end{array}$ & [180] \\
\hline TGP (Mebiol gel) & Shear Storage/Loss modulus & $\begin{aligned} \mathrm{G}^{\prime} \sim 0.8 \mathrm{kPa}\left(\sim 37^{\circ} \mathrm{C}\right) \\
\mathrm{G}^{\prime \prime} \sim 0.2 \mathrm{kPa}\left(\sim 37^{\circ} \mathrm{C}\right)\end{aligned}$ & [181] \\
\hline HAMC & Shear Storage/Loss modulus & $\begin{aligned} \mathrm{G}^{\prime} & <0.1 \mathrm{kPa} \\
\mathrm{G}^{\prime \prime} & <0.1 \mathrm{kPa}\end{aligned}$ & [182] \\
\hline Microporous HA & Elastic modulus & $\mathrm{E}=1.5 \mathrm{kPa}$ & [183] \\
\hline $\begin{array}{l}\text { Laminin peptide } \\
\text { sequence IKVAV }\end{array}$ & Shear Storage/Loss modulus & $\begin{aligned} \mathrm{G}^{\prime} & =0.8-1.0 \mathrm{kPa} \\
\mathrm{G}^{\prime \prime} & =0.1-0.4 \mathrm{kPa}\end{aligned}$ & [184] \\
\hline HA-IKVAV-MPP & Shear Storage/Loss modulus & $\begin{array}{c}\mathrm{G}^{\prime}=0.47-1.6 \mathrm{kPa} \\
\mathrm{G}^{\prime \prime}<0.1 \mathrm{kPa}\end{array}$ & [185] \\
\hline ECM-UBM & Shear Storage/Loss modulus & $\begin{aligned} \mathrm{G}^{\prime} & =0.07-0.46 \mathrm{kPa} \\
\mathrm{G}^{\prime \prime} & <0.01-0.06 \mathrm{kPa}\end{aligned}$ & [186] \\
\hline Chitosan & Shear Storage/Loss modulus & $\begin{array}{c}\mathrm{G}^{\prime}=0.8-1.5 \mathrm{kPa} \\
\mathrm{G}^{\prime \prime}=0.001-0.01 \mathrm{kPa}\end{array}$ & [187] \\
\hline Alginate & Shear Storage/Loss modulus & $\begin{aligned} \mathrm{G}^{\prime} & =0.8-1.5 \mathrm{kPa} \\
\mathrm{G}^{\prime \prime} & =0.4-0.5 \mathrm{kPa}\end{aligned}$ & [187] \\
\hline Silk fibroin & Elastic modulus & $\mathrm{E}=6-30 \mathrm{kPa}$ & [188] \\
\hline
\end{tabular}

Crosslinking is generally produced by physical non-covalent hydrophobic-ionic interactions and/or covalent bonds between chemical groups. The crosslinking-density and the relative amount of free and bound water is a main determinant of pore size and tridimensional structure. Natural and artificial hydrogels can be used alone or in combination. Naturally derived biomaterials are usually non-toxic; however, it is difficult to control their biodegradability and there are batch-to-batch variations in the production of the material that represent a source of variability in relation to their physical properties. Poor control of degradation in some natural polymers might be justified by the presence of degradation motifs such as hydrolysable ester groups and enzyme-mediated hydrolytic amide elements. An advantage of natural polymers is that they usually contain native binding sites to favor cell interaction and anchoring. Synthetic polymers in contrast have relatively well-controlled structures and their microstructure and properties including: pore size, degradation, functionalization, shape, sterilizability, and stiffness are adjustable. In comparison with natural materials, synthetic polymers might be created to mimic more efficiently the physical and mechanical properties of brain tissue. Synthetic polymers are usually non-inmunogenic, but may contain toxic products related to the fabrication and purification processes [189]. Generally, natural hydrogels might trigger host immune responses while synthetic ones no. To enhance biocompatibility and mimic the extracellular microenvironment, the hydrogel chemistry can be modified by adding different molecules and materials as for example gelatin, heparin or the tripeptide Arg-Gly-Asp (RGD), the principal integrin-binding motif present in matrix proteins such as fibronectin and some laminins and collagens to facilitate cell attachment and survival. Artificial hydrogels with degradable units such as poly ( $\alpha$-hydroxy acids) and poly(glycolic acid) can be synthetized, so that their constituent 
monomers dissociate in contact with water. Alternatively, other hydrogels, such as poly( $\varepsilon$-caprolactone) can be also enzymatically degraded by lipases.

One of the first studies using biomaterials for in vivo applications was performed in the 1980s [190]. Yannas and Burke performed skin implants in guinea pigs using collagen membranes and observed a limited inflammatory response by detecting mono- and polynucleated cells. This immune response against the implanted biomaterial could be minimized by crosslinking collagen with glucosaminoglucan. Later, Vacanti et al. cultured mouse and rat hepatocytes into artificial polymers composed of polyglactin, polyorthoesters, and polyanhydride for subsequent liver transplantation in rats, demonstrating that hepatocytes remained viable up to 14 days after in vivo implantation [191]. In the same period, a pioneer study showed prolonged in vivo survival and function of pancreatic islets encapsulated into cross-linked alginate microcapsules [192]. These studies provided some conceptual basis for the development of tissue engineering. Since then, a wide variety of applications in the field of regenerative medicine for different tissues and organs has been reported using hydrogel-based biomaterials to enclose different cells, drugs and different growth factors.

\subsection{Hydrogels for Brain Repair}

The first biomaterials for applications related to CNS disorders were assayed nearly three decades ago by Woerly et al., who intracerebrally implanted several materials with a base of collagen to enhance cellular attachment and provide pathways of migration for regenerating axons, transplanting a mix of polymers based on poly(glyceryl methacrylate) (pGMA) and poly(2-hydroxyethyl methacrylate)-collagen (pHEMA) in the cortex of adult rats. In their studies, astrocytes from the brain colonized the interior of the hydrogels. Although not immunophenotypically characterized, this cellular invasion responded to astrogliosis against the injection of the material in a formed hydrogel state and the nature of the materials used [193,194]. Lesny et al. replicated the Woerly assays using a similar composite of polymers (including pHEMA), confirming how hydrogels were colonized by reactive astrocytes up to eight weeks post-implant [195]. Thus, based on the ability of glial cells to enter inside these biomaterials, it was postulated that these polymers could be exploited in combination with different cell populations, constituting a viable approach to favor cell engraftment after implantation into the brain. Subsequently, poly-hydroxypropylmethacrylamide (HPMA) hydrogels were used to engraft eSCs and mSCs as imageable scaffolds for in vivo magnetic resonance in experimental models of spinal cord injury [196]. After this initial period, the use of biomaterials for neuroscience has continued to grow substantially over the years, providing examples of how the integration of cells and/or neurotrophic factors into biomaterials with different natures and composition enhanced the improvement of functional recovery in affected animals with respect to the therapeutic implantation of cells/factors without the biomaterial $[13,14,144,197]$. The different in vitro studies have provided support for the compatibility of distinct hydrogel-based biomaterials on the growth, differentiation, and function of different stem cells and progenitors as well the mechanistic aspects of differentiation and secretion of neuroprotective, neuroregenerative, and angiogenic factors [198-203]. However, the in vivo studies have provided a more definitive proof of the concept of the neuro-therapeutic potential of stem cells/progenitors $[135,144,197,200,204]$ and different factors [7,205-209] cerebrally injected with different biomaterials. Any biomaterial of choice should provide a suitable microenvironment for the survival of the implanted cells, favoring cell engraftment in the host tissue $[144,155,210,211]$. Experimental data suggest that cellular behavior might be influenced by the nature of the biomaterial employed and the physical and chemical hydrogel properties [212]. For example, it has been described how extracellular matrix (ECM) stiffness affects stem cell maintenance, differentiation and function [213,214]. For cell engraftment in the brain parenchyma, an ideal hydrogel would be one with an adequate conformational structure and mesh size for cell lodging allowing the release of trophic factors, the entry of nutrients, and the output of waste products to create a barrier to protect therapeutic cells from a hostile microenvironment such as the damaged brain, because of the inflammatory and immune system response induced by 
injury. In addition, porosity of hydrogels can be tuned creating pores large enough to allow neurite extension and vascularization between the host brain and the implanted hydrogel [167]. As hydrogels are designed for soft tissues such as the brain, they are mechanically weak and difficult to handle in formed hydrogel state. However, hydrogels can be formed in situ under physiological conditions once a polymer (or mix of them) have been implanted as a liquid in the brain, making it easy to incorporate cells and factors before gelation, thus reducing the invasiveness of hydrogel implantation instead of using a formed hydrogel state [188,215]. This strategy allows, for example, the hydrogel to fill completely amorphous cavities as the result of injury, whereas formed hydrogels are not suitable for this type of applications.

In this regard, one of the basic design parameters of the hydrogel is the density of functional groups (i.e., acrylates, thiols, and polyesters) in the polymer backbone. The density of functional groups may influence the space between cross-links during polymerization, so that a higher density leads to hydrogels with a tighter mesh structure. Different strategies to induce hydrogel gelification have been developed for in vitro and in vivo applications [188,216,217]. Hydrogel polymerization can be prompted by changes in temperature, ionic concentration and $\mathrm{pH}$. Alternatively, polymerization can also be induced by ultraviolet exposition (photopolymerization) or sonication [188] (Figure 2). An interesting property of certain hydrogel-based biomaterials depends on their ability to polymerize in situ at body temperature in certain concentration ranges. However, a major limitation of injectable hydrogels resides in the uncontrollable gelation kinetics. If gelation occurs too fast, obstruction of the needle can be produced during delivery. If the gelation is too slow, cells and factors enclosed into the biomaterial might disperse out of the brain site of implantation. In other scenarios the in situ polymerization does not result adequate, for example in peripheral nerve regeneration where axonal outgrowth probably needs biomaterial scaffolds with a pre-defined tubular shape to favor axonal guidance [218]. Once the neurotherapeutic effect has been concluded, hydrogels should degrade into non-cytotoxic and non-inflammatory by-products [219]. Often, degradation occurs by hydrolytic or enzymatic cleavage of bonds established between monomers during polymerization. Degradation might be useful for example to promote neurite extension from neural cells encapsulated into hydrogels at discrete sites of the hydrogel material allowing a certain control on the axonal sprouting and neural connectivity with the host tissue.

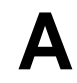

Natural polymers
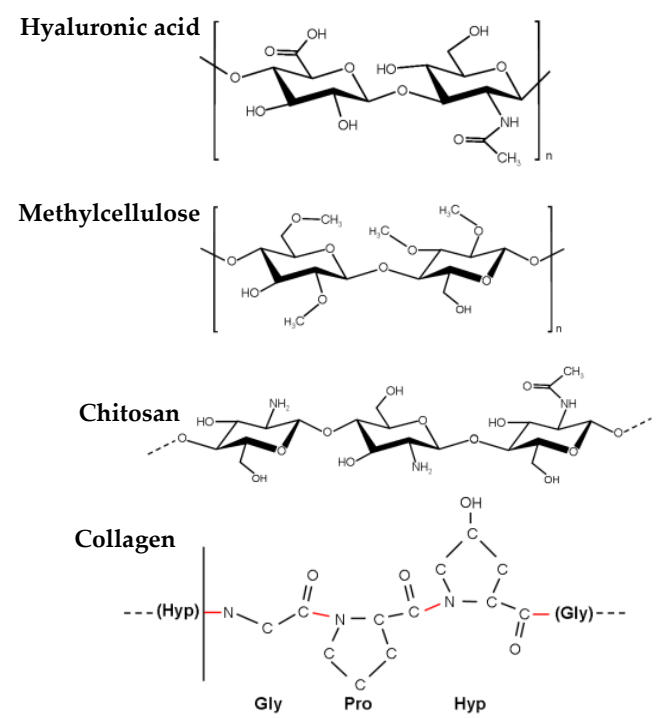

Synthetic polymers

PLGA

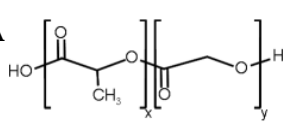

PEG

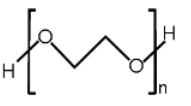

TGP

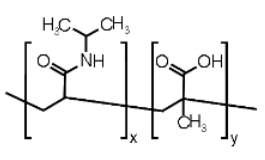

TRP

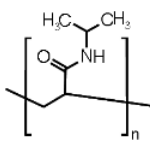

Figure 2. Cont. 


\section{B}

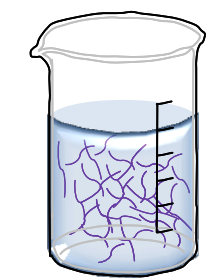

Polymeric solution

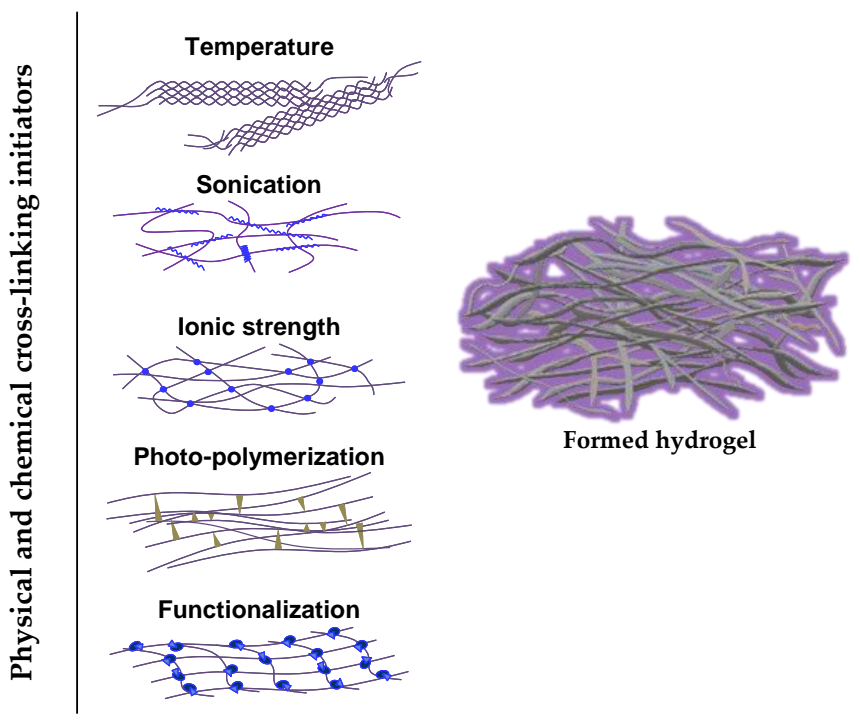

Figure 2. Hydrogel-based biomaterials for brain repair. (A) Chemical structure of the more frequent biomaterials and their constituent monomers used in neurorestorative therapies. (B) Hydrogel polymerization can be induced by physical and chemical cross-linking. Representative cross-linking initiators are temperature, electric/magnetic fields, ultraviolet exposition (photopolymerization), sonication, $\mathrm{pH}$, ionic strength, solvent composition or functionalization among others. The cerebral implantation of hydrogel polymers (alone or in combination with cells) can be performed using the biomaterial in a formed state (polymerized before brain implantation) or injected as a liquid in the brain (pre-gel) to be formed in situ under physiological conditions. This latter approach reduces the invasiveness of biomaterial implantation allowing the hydrogel to fill amorphous cavities as the result of injury. PLGA: poly(lactic-co-glycolic acid); PEG: Poly(ethyleneglycol); TGP: poly( $N$-isopropylacrylamide-co- $n$-butyl methacrylate); TRP: poly( $N$-isopropyl- acrylamide).

The combination of cells and hydrogels in pre-clinical models of neuro-restoration dates back to the last decade [220]. For the encapsulation of cells and factors, different natural and synthetic polymers alone or in a mix, have been manufactured including gelatin, polyethylene glycol (PEG), alginate, hyaluronic acid (HA), collagen, heparan sulfate proteoglycans, laminin, Matrigel, chitosan, polyacrylamide or PLGA, among others [221,222]. The possibility of integrating cells and factors into hydrogels for subsequent co-transplantation constitutes a strategy that may enhance cell survival, retention, and function as well as sustaining the delivery of different molecules when the material is injected within the stroke cavity, in peri-infarcted areas, epicortically, or in the brain striatum $[7,156,181,183,206,209,210,223,224]$. One of the most frequently used biomaterials for brain regeneration applications is hyaluronic acid, a high-molecular weight nonsulfated

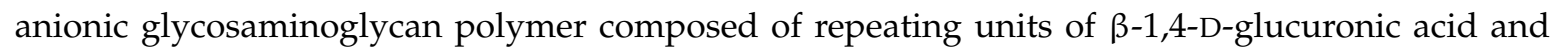
$\beta-1,3-N$-acetyl-D-glucosamine (Figure 2). HA constitutes an abundant component of extracellular matrix in the brain, playing specific roles in cell adhesion proliferation and fate as well as providing signaling for wound repairing, angiogenesis or morphogenesis. To improve cell neural attachment and survival, HA hydrogels can be chemically modified with polylysine and RGD peptides [225]. In general, natural hydrogel polymers such as HA are more susceptible to suffer in vivo degradation via enzymes from the host tissue. For example the enzyme hyaluronidase, which is secreted by neurons and some glia, increases the rate of HA degradation in vivo. HA can be also degraded by ( $-\mathrm{D}-$-glucorinadases and ${ }^{\circledR}-\mathrm{N}$-acetyl-hexosaminidases. Another material that has been used to a lesser extent for the treatment of neurological disorders is collagen, which represents a major structural component of extracellular matrix in various tissues. Functional collagen appears as a triple-helix and may lead to the formation of long fibers. Collagen can be also cross-linked to a variety of bioactive molecules by different physical and chemical procedures to favor interaction with cells and 
surrounding tissues. The sequences of amino acids Proline (Pro)-Hydroxyproline (Hyp)-Glycine (Gly) constitute the most common triplets $(10.5 \%)$ in collagen (Figure 2 ). The natural biocompatibility of this biomaterial with many tissues represents a strong advantage for the design and fabrication of collagen hydrogels to support cerebral cell implantation. In contrast to the proteinaceous nature of collagen, chitosan is a natural polysaccharide produced by deacetylation of chitin formed by D-glucosamine and N-acetyl-D-glucosamine units (Figure 2). This biomaterial found in many arthropods is highly enriched in basic polysaccharides and has been used in a variety of different biomedical chitosan-based hydrogel applications. In addition, their mechanical properties can be tuned to mimic stiffness of many tissues including brain [187]. Alginate is a natural anionic polysaccharide extracted from algae composed of two monosaccharides of $\alpha$-L-guluronic acid and $\beta$-D-mannuronic acid. The mechanical properties can be modified by the interaction of this biomaterial with divalent cations creating a dense 3D network. Intracerebral transplantation of alginate microcapsules has been used to neuroprotect the ischemic brain [226]. Several artificial polymers were also used for forming hydrogels in brain therapies. In this regard, PLGA is one of most commonly used biodegradable synthetic polymers in tissue engineering. PLGA is a linear copolymer that can be fabricated at different ratios from its main constituents: the cyclic dimers of lactic acid and glycolic acid. This biomaterial can be dissolved in a wide range of common solvents and be processed into any shape and size for encapsulation of factors, drugs and different cells. The chemical properties of PLGA allow hydrolytic degradation to produce the original monomers through de-esterification. PLGA degradation can be tuned by changing the ratio between monomers. This biomaterial has resulted very compatible in multiple applications including the functional restoration of damaged brain (Table 2). Additionally, PLGA microspheres at different rates based on PLGA carboxylation have been used to accelerate the release of different growth factors [227].

Several are the evidences supporting the therapeutic role of biomaterials, cells and factors for brain repair (Figure 3). In a representative study using a model of hypoxia-ischemia in mice, the intracerebral transplantation of nSCs cultured on scaffolds of polyglycolic acid (PGA) fibers (10-15 $\mu \mathrm{m}$ in diameter) inside the ischemic cavity resulted in axonal rewiring among the donor and host tissue with minimal adverse effects [204]. Although no functional evolution was examined, the study established a precedent in the co-transplantation of biomaterials and therapeutic cells in different models of cerebral damage. Later, HA hydrogels were constructed with laminin immobilized on the HA backbone and implanted in formed hydrogel state into the lesioned cortex of brain rats [178]. In this case the HA hydrogels were produced by cross-linking HA sodium salt with adipic dihydrazide (ADH) and carbodiimide, yielding elastic modulus below $1 \mathrm{kPa}$. These HA hydrogels functionalized with laminin sufficed to reduce astrogliosis and inflammation after injury as well as promote new vessels formation (angiogenesis) and neurite extension, a substrate for neuron-to-neuron connectivity [178]. The anti-inflammatory character of HA has been corroborated with other formulations based on this biomaterial $[178,198]$. For example HA hydrogels produced after chemical reaction with ADH derivates, were modified with anti-Nogo receptor antibody and poly-L-lysine and were embedded with PLGA microspheres functionalized with VEGF and angiopoietin-1 though water-in-oil-in-water emulsion techniques [198]. This HA-PLGA hydrogel composite was implanted in formed hydrogel state into the injury cavity of stroke mice attenuating the scar formation and the inflammatory response determined by the astrocytes content as wells as promoted angiogenesis and post-stroke behavioral improvement [198]. All these formulations led to hydrogels close to $1 \mathrm{kPa}$. 

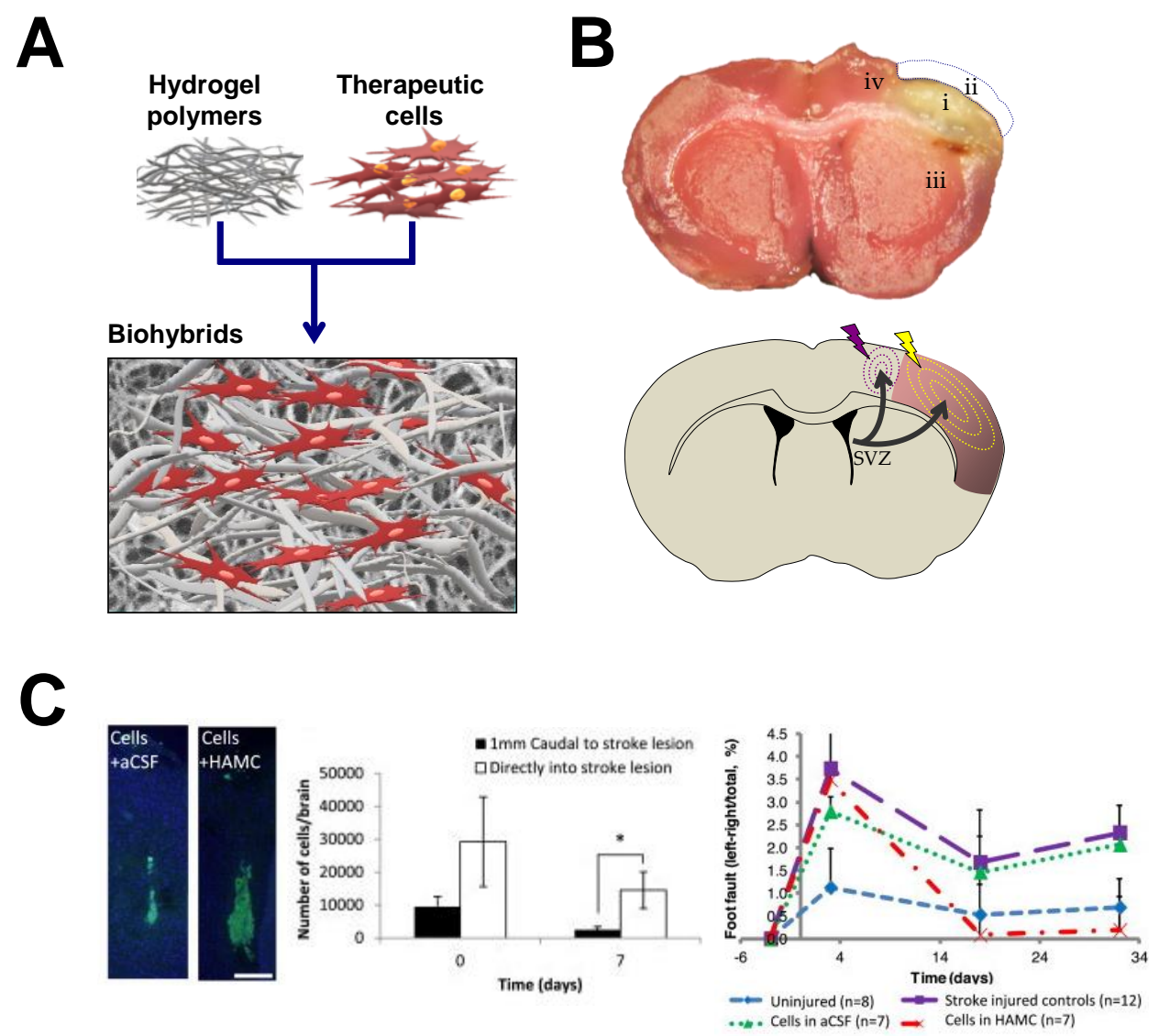

Figure 3. Neurorestorative potential of hydrogel-based biomaterials in ischemic stroke. (A) For encapsulation of cells and factors, different natural and synthetic polymers alone or in a mix have been manufactured and injected into different anatomic brain regions. (B) On the top, representative image of a coronal brain section stained with triphenyltetrazolium chloride (TTC) $24 \mathrm{~h}$ after distal middle cerebral artery occlusion, one of the stroke rodent models more regularly used [8]. In this model, the infarct area is mainly restricted to the brain cortex ("white" area in the right hemisphere) and the implantation of cells and hydrogels has been generally performed at different regions including: the stroke cavity (i); epicortically (ii); striatum (iii); or in the cortical area bordering the lesion cavity (iv). On the bottom, SCs might neuroprotect the brain by diminishing apoptosis and the post-ischemic inflammatory response. Furthermore, functional recovery induced by hydrogels and cells might be ascribed to regenerative processes in the damaged tissue (illustrated in the scheme by yellow dashed lines) or structural changes (tissue remodeling) in perilesional regions (violet dashed lines). Most of these changes are produced by previous stimulation of endogenous neurogenesis in the sub-ventricular zone (SVZ). (C) Example of the neuro-therapeutic potential of neural stem cells and progenitors (nSCs) integrated into hyaluronan-methylcellulose (HAMC) hydrogels. The engraftment and survival of nSCs into the mouse brain was favored when injected in HAMC hydrogels (left graph, scale bar $200 \mu \mathrm{m}$ ), with higher rates of survival when the cells enclosed in the biomaterial were injected into the stroke lesion (endothelin-1 model) than when they were implanted in healthy areas surrounding the damaged tissue (middle graph). The mice transplanted with nSCs delivered in HAMC hydrogels showed significant post-stroke functional recovery (right graph). Results in (C) reproduced with permission from [155], published by Cell Press, Elsevier Inc., 2015.

In other example, a high molecular HA modified with glycidyl methacrylate to create a photocrosslinkable HA polymer was used for spinal cord HA hydrogel implantation. In this case the compressive moduli reached a higher value of $\sim 7.9 \mathrm{kPa}$. This value of the elastic modulus is similar to the value determined by the same group in the adult rat brain $(5.7 \mathrm{kPa})$ and spinal cord $(8.0 \mathrm{kPa})$ [177]. Once injected as a hydrogel this HA polymer reduced the inflammatory cell infiltration 
and gliosis on the surrounding tissue after spinal cord injury. In another study, a biodegradable porous gelatin-siloxane 3D scaffold formed by the integration of gelatin and 3-glycidoxypropyl trimethoxysilane was used to provide the gradual secretion of EGF/FGF neurothrophic factors [228]. When this material was implanted alone into the brain, the inflammatory response determined by the microglia content was minimal, thus supporting the biocompatibility of this biomaterial scaffold. The combined implantation of EGF/FGF with this biohybrid promoted tissue regeneration inferred by the accumulation of 5-Bromo-2'-deoxyuridine-proliferative cells, dendrite elongation, and endothelial vascular cell expansion, suggestive of active angiogenesis [228].

Table 2. In vivo studies using different cell populations in combination with distinct biomaterials to restore the functionality loss after brain stroke.

\begin{tabular}{|c|c|c|c|}
\hline $\begin{array}{l}\text { Stroke model, } \\
\text { specie }\end{array}$ & $\begin{array}{l}\text { Biomaterial, cell population, } \\
\text { site of implantation }\end{array}$ & Therapeutic effects & References \\
\hline CCAO, mouse & PGA, nSCs, infarct cavity & $\begin{array}{l}\text { Increasing axonal rewiring, reduction of } \\
\text { inflammation and glial scar formation }\end{array}$ & [204] \\
\hline MCAO, mouse & TGP, mSCs, brain surface & $\begin{array}{l}\text { Increasing engraftment of transplanted cells, } \\
\text { increasing neuronal differentiation, no } \\
\text { functional improvement }\end{array}$ & [181] \\
\hline MCAO, mouse & HA alone, infarct cavity & $\begin{array}{l}\text { Reduction of inflammation and glial scar, } \\
\text { enhanced perilesional vascularization, } \\
\text { stimulation of endogenous neurogenesis }\end{array}$ & [183] \\
\hline $\mathrm{MCAO}$, rat & PLGA, nSCs, infarct cavity & $\begin{array}{l}\text { Cavity size reduction, increasing engraftment } \\
\text { of transplanted cells, de novo tissue formation }\end{array}$ & [156] \\
\hline $\mathrm{MCAO}$, rat & Matrigel, eSCs-nPCs, infarct cavity & $\begin{array}{l}\text { Reduction in lesion size, increasing survival of } \\
\text { transplanted cells, neuronal and astroglial } \\
\text { differentiation, neuronal migration, } \\
\text { improvement of behavioral outcome }\end{array}$ & [135] \\
\hline $\mathrm{MCAO}$, rat & Col I, nSCs, infarct cavity & $\begin{array}{c}\text { Increasing survival of transplanted cells, } \\
\text { neuronal differentiation, increasing } \\
\text { synaptogenesis, improvement of } \\
\text { behavioral outcome }\end{array}$ & [229] \\
\hline $\mathrm{MCAO}$, rat & PLGA-VEGF, nSCs, infarct cavity & $\begin{array}{l}\text { Hipervascularization linked with astrocytic } \\
\text { differentiation, limited neuronal commitment }\end{array}$ & [230] \\
\hline $\mathrm{MCAO}$, rat & TRP, mSCs, brain surface & Improvement of motor function & [231] \\
\hline PTS, mouse & HA, iPSCs -nPCs, infarct cavity & $\begin{array}{l}\text { Enhancing survival of transplanted cells, } \\
\text { reduction of post-stroke inflammation, } \\
\text { increasing neuronal and } \\
\text { astrocytic differentiation }\end{array}$ & {$[180,232]$} \\
\hline PTS, mouse & $\begin{array}{l}\text { HA-heparin-Col, eSCs-nPCs, } \\
\text { infarct cavity }\end{array}$ & $\begin{array}{l}\text { Increasing survival of transplanted cells, } \\
\text { reduction of inflammation and glial scar }\end{array}$ & [233] \\
\hline ET-1, mouse & HAMC, nSCs, infarct cavity & $\begin{array}{c}\text { Increasing survival of transplanted cells, } \\
\text { astrocytic differentiation, limited neuronal and } \\
\text { oligodendrocyte commitment, improvement of } \\
\text { behavioral outcome }\end{array}$ & [155] \\
\hline ET-1, rat & $\begin{array}{c}\text { Self-assembling IKVAV peptide } \\
\text { (laminin epitope), eSCs-nPCs, } \\
\text { infarct cavity }\end{array}$ & $\begin{array}{l}\text { Increasing survival of transplanted cells, tissue } \\
\text { regeneration, cell adhesion and axonal growth, } \\
\text { improvement of behavioral outcome }\end{array}$ & [184] \\
\hline \multicolumn{4}{|c|}{ 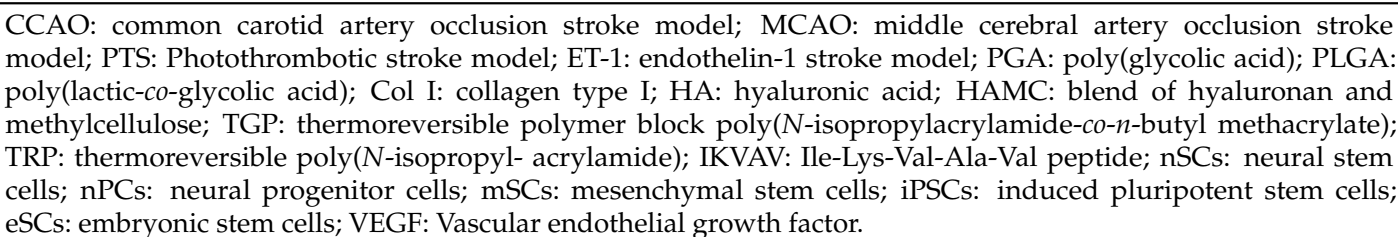 } \\
\hline
\end{tabular}

As a result of the promising outlook of the therapeutic approach, an increasing number of biomaterials in different formats have been assayed and extended in a wide variety of experimental brain damage models in the last decade (Table 2). Some of the most salient outcomes in neurorestorative therapies for stroke using advanced polymers in combination with different therapeutic cells are summarized below. For example, Jin et al. showed in rats that transplantation in the infarcted cavity of human eSCs-derived neuronal progenitors mixed with a suspension of liquid Matrigel for in 
situ gelation at body temperature improved sensorimotor, memory, and learning deficits after focal ischemia induced by occlusion of the middle cerebral artery [135]. Only the exclusive combination of cells and Matrigel was associated with a reduced cavity size, better survival of transplanted cells when integrated into the biomaterial and improvement of functional outcome. Although the experimental treatment was initiated three weeks after infarction, the behavioral improvement observed in the animals suggest that it is possible to rescue the brain damage at even longer times after injury, when the infarction and functional deficits has been definitively established and the inflammation is resolved [135]. In other study, injectable PLGA microparticles were fabricated through single oil-in-water emulsion technique and functionalized with allylamine and coated with fibronectin to provide structural support for nSCs. Once implanted into the stroke cavity new cerebral tissue was generated and cell morphology and behavior of transplanted cells was dependent on cell position relative to the infarct core, suggesting that the inhospitable core influenced on transplanted cells differentially with respect to the effect exerted by the perilesional tissue [156]. When these PLGA microparticles were modified with VEGF, endogenous endothelial cells chemo-attraction, migration and proliferation were observed to develop new vascular networks that might sustain the function of a de novo tissue within the stroke cavity [230]. A different combination of thiol-modified sodium HA cross-linked with heparin sulfate, collagen (gelatin) and polyethylene glycol diacrylate has been used to transplant eCS-derived neural progenitors into the lesion cavity of stroke mice [233]. This hydrogel matrix was able to polymerize at body temperature after brain injection. Although the mechanical properties of this biomaterial were not characterized in this study, it was shown that this mixture of polymers did not cause deformation of the brain after transplantation suggesting that the elastic properties were in the range of cerebral tissue. In addition, the hydrogel promoted the survival of transplanted cells and their differentiation into astrocytes and neurons in vivo. Another interesting finding was that the hydrogel alone diminished the post-stroke inflammatory reaction, a remarkable characteristic of HA-based biomaterials [233]. In yet another study, HA hydrogels with storage modulus in the range of $0.3-0.8 \mathrm{kPa}$ favored the in vitro neural differentiation of iPSCs-derived nSCs [179]. In the in vivo context the same group used HA hydrogels functionalized through a Michael addition of acrylates present in the HA backbone with di-cysteins present in a matrix metalloproteinase degradable peptides [180]. These combined HA hydrogels presented a storage modulus of $0.3 \mathrm{kPa}$. When cerebrally injected in liquid format in combination with iPSCs-derived $\mathrm{nSC}$ for in situ polymerization into the infarct cavity, the inflammatory response exerted by this HA-based biomaterial was minimal, in contrast to the greater inflammatory response observed after transplantation of HA polymers with storage moduli in excess of $1.0 \mathrm{kPa}$ [180]. Thus, it is accepted that mechanical characteristics of hydrogels influence the degree of biocompatibility of the biomaterial and its integration into the host tissue [224], and stiffness properties close to the brain tissue are generally associated with lower inflammation and/or minor toxic effects. Despite this HA hydrogel caused minimal inflammation however it did not enhance survival of transplanted cells although significant neuronal differentiation was promoted [180]. Similarly, a fast ( $10 \mathrm{~min})$ in situ gelation polymer-based hydrogel composed of acrylated-HA, matrix metalloproteinase degradable and non-degradable motifs, adhesion peptides and heparin functionalized with thiol groups was used for cerebral implantation of iPSCs-derived nSCs [232]. This HA-hydrogel, with an elastic modulus in the range of 0.1-1.0 $\mathrm{kPa}$, favored the survival of iPSCs-derived nSCs promoting glial and neuronal differentiation. By contrast, a copolymer of poly( $N$-isopropylacrylamide) and poly(ethyleneglycol) has been used to satisfactorily engraft mSCs into the mouse brain. This thermosensitive hydrogel with a sol/gel transition temperature of $\sim 20^{\circ} \mathrm{C}$ and storage modulus in the range of $0.5-1.0 \mathrm{kPa}$ was implanted as a fully formed hydrogel over the brain cortex surface. Although no significant post-stroke recovery was observed after treatment in the interval of eight weeks of analysis, no significant inflammatory response induced by this specific copolymer was detected either [181]. In contrast, post-stroke functional recovery was efficiently enhanced in rats after epicortical transplantation of a another reversible temperature-responsive polymer (cell-sheet format) based on poly( $N$-isopropylacrylamide) 
in combination with mesenchymal progenitor stromal cells [231]. In another study with rats, nSCs were cerebrally transplanted together with porous 3D collagen sponges, which enhanced the survival of engrafted cells and synapse formation as well as improved neurological function after stroke [229]. An interesting observation with this study was that the collagen degraded completely thirty days after the biomaterial implantation, which might suppose a limitation with this biomaterial if persistent therapeutic stimulation is needed. Other combinations of biomaterials have been also tested. For example, a fast-gelling injectable in situ hydrogel mixture of HA modified with acetic hydrazide through carbodiimide chemistry and methylcellulose (MC), favored nSCs engraftment in the damaged brain, enhancing post-stroke motor recovery in an endothelin-1 mouse stroke model [155] (Figure 3). In addition, the transplanted nSCs differentiated into astrocytes and to a minor extent gave neurons and myelinating oligodendrocytes [155]. Although the mechanical properties of this hydrogel matrix were not assessed in this study, polymers with the same composition (HA and MC), but with slightly different proportions, showed elastic moduli inferior to $0.1 \mathrm{kPa}$ [182]. In contrast, a blend of HA and MC injectable hydrogel, that was tested in the same stroke rodent model (endothelin-1), did not result in better survival of cerebrally transplanted iPS-derived neuroepithelial stem cells. It was hypothesized that the lack of a therapeutic effect might be attributable to the stresses produced by the flow of the cells along the needle, in addition to the extensional flow of cells in the transition syringe/needle during cerebral injection [200]. Very recently an interesting finding has been reported after the implantation of an advanced injectable porous HA hydrogel in the stroke cavity of infarcted mice after middle cerebral artery occlusion [183]. In a similar way to [180], this hydrogel was synthesized through carbodiimide chemistry to introduce acrylamide groups on the HA backbone. The biomaterial was functionalized with several peptides (including the RGD tri-peptide) and then cross-linked through Michael-type addition using di-cysteins present in matrix metalloproteinase degradable peptides giving a hydrogel scaffold with an elastic modulus of $1.5 \mathrm{kPa}$ [183]. One difference with HA hydrogels of limited-porosity is that the implantation of this porous HA hydrogels was translated into a post-stroke reduced scar thickness, decreasing inflammatory microglia, and enhanced perilesional vascularization. In parallel, these porous HA gels stimulated the infiltration and migration of endogenous neural progenitors cells from the SVZ (neurogenic niche) towards the perilesional and stroke cavity regions, which could be related to an increasing infiltration of astrocytes [183]. Recently, a self-assembling peptide-based scaffold composed of repeating units of the IKVAV peptide sequence present in the major ECM protein laminin has been engineered [184]. This binding domain sequence (IKVAV) has been involved in neuronal adhesion, migration, proliferation differentiation and neurite guidance and outgrowth [234]. The IKVAV-injectable hydrogel with rheological elastic shear moduli below $1.0 \mathrm{kPa}$ was implanted together with human eSCs-derived cortical progenitors into the lesion cavity of stroke rats (endothelin-1 model). This approach favored long-term survival of eSCs-derived cortical progenitors as well as promoted neuroprotection, cell replacement through the appearance of de novo tissue and supported cell adhesion and axonal growth, all of them mechanisms that contributed to enhance post-ischemia functional recovery [184]. The IKVAV sequence has been also previously used to functionalize HA-based polymers [185]. In this case, IKVAV peptides and metalloproteinase were immobilized to acryl groups of acrylated-HA through Michael type reaction giving HA hydrogels with elastic modulus in the range of $0.5-1.6 \mathrm{kPa}$. These copolymers were mixed with BDNF through electrostatic interactions to sustain BNDF release, and were also combined with human mSCs, enhancing nerve regeneration and recovery in a model of spinal cord injury in rats [185]. The biomaterial composition and stiffness of the implanted hydrogels not only affects the macrophages/microglia infiltration (a measure of inflammation) modifying the microglia M1/M2 balance [186], but also impacts on the in situ formation and retention of hydrogels in the stroke cavity, as it has been for example demonstrated in rats transplanted with an injectable ECM urinary bladder matrix-based hydrogel with storage modulus in the range of $0.07-0.4 \mathrm{kPa}$ [186]. In this case, injection of higher ECM concentrations $(>3.0 \mathrm{mg} / \mathrm{mL}$ ) gelled within the stroke cavity, resulting in an extensive distribution and retention of the biomaterial within the cavity while reduced ECM concentrations were associated with permeation 
of ECM into the perilesional tissue [186,235]. Interestingly, when higher concentrations of this ECM hydrogel $(>8.0 \mathrm{mg} / \mathrm{mL})$ were injected into the stroke cavity, the biomaterial provided structural support to the surrounding healthy host brain tissue reducing the lesion cavity [235]. Collectively, these studies help us understand the importance of the design of a hydrogel with a defined structure and composition to provide a directed interaction with the cerebral microenvironment upon the pathological state resulting in minor damage and enhancing repair after injury. The applicability of stem cells and biomaterials has been tested in other neurological diseases of sudden onset, for example, traumatic brain injury (TBI). In rats, one week after TBI, the transplantation of a biodegradable injectable collagen gel favored donor mSCs survival and retention in the lesion core [236]. Although mSCs alone enhanced functional recovery, this effect was potentiated with the inclusion of this cell population in the biomaterial. In other example, the survival of nSCs was potentiated across eight weeks when this cell population was transplanted into the lesion cavity together with laminin/collagenor fibronectin/collagen-based scaffolds with in situ gelation [237]. Similarly, this strategy induced progressive behavioral improvement after TBI in mice [237].

Across the different studies, the benefits of implanting SCs together with different biomaterials has been related to the modification (reduction) of post-stroke damaged areas; the formation of new vessels (angiogenesis) in the infarcted and peri-infarcted regions; or in the neuro-restitution and plasticity phenomena. In the case of angiogenesis, it is extensively accepted that vascular formation stimulates endogenous recovery mechanisms, creating an adequate microenvironment for endogenous proliferation migration and differentiation, thus supporting neural restitution, synaptogenesis, axonal growth, and neuro-plasticity [238]. These main therapeutic mechanisms are probably the result of the increasing survival and longer retention of implanted cells in the brain tissue, which is assisted by the different biomaterials used, favoring a persistent release of different neurotrophic factors responsible for the observed effects. Alternative approaches based on the direct implantation of different neurotherapeutic factors and hydrogels have been also developed and studied $[239,240]$. For example, two inducers of angiogenesis, VEGF and angiopoietin-1, have been implanted together with HA and PLGA in stroke models [198]. An enhanced stimulation of endogenous nSCs in parallel with the proliferation of neural progenitors have been found after the controlled release of cyclosporin $\mathrm{A}$ via a combination of HA and MC applied epicortically in rats submitted to stroke [7]. Post-stroke neurogenesis and axonal connectivity in the perilesional area promoted motor recovery after the controlled release of BDNF through HA hydrogels [206]. In another example, a hyaluronan/heparan sulfate hydrogel was used to control the delivery of antibodies against ephrin A, enhancing axonal sprouting and functional recovery [145].

\subsection{Toxicity and Adverse Concerns}

A deep reflection on the possible clinical applicability of the synthetic and/or natural biomaterials that are being used in the current brain damage models is necessary given that, with most biomaterials, the short- and long-term adverse effects derived from the implant into the brain are unknown. Many studies have focused on examining the therapeutic effects of a particular biomaterial alone or in combination with different cell populations without considering the analysis of additional cytotoxicity and inflammation induced by the material itself. In many cases, the compatibility of the biomaterials with brain-derived neural cell populations has been tested exclusively in vitro. However, in vitro studies offer a reductionist view of the tolerability of biomaterials with respect to in vivo approaches where it is possible to examine how the biomaterial can be integrated with the brain analyzing the host bioresponse towards the graft. For example, HA, one of the most frequently used biomaterials for experimental brain repair, does not produce significant astrogliosis, microgliosis, or increase neuronal death in the normal brain [145]. In fact, some tunable HA hydrogels with non-restricted permeability reduced the post-stroke inflammatory response [183]. However certain fragments of hyaluronan can trigger the innate immune response activating alloimmunity [241]. In this context, any biomaterial should be non-toxic both as a fully polymerized hydrogel and as any by-product that 
may be generated during its degradation. In this regard, the accumulation of HA has been related to aging processes and demyelinating diseases such as multiple sclerosis. Some forms of hyaluronan produced by astrocytes accumulate in demyelinated lesions avoiding the remyelination of neuronal circuits after brain damage [242,243]. Although a clear positive effect of HA promoting post-stroke recovery (including the reduction of inflammation) has been reported, reasonable doubts emerge with the usefulness of this biomaterial for application in other neurological disorders when considering the clinical perspective. As discussed previously, other biomaterials with proven neuro-therapeutic potential are collagen, chitosan, PLGA, or Matrigel. However, the use of collagen as a biomedical implant raises safety concerns related to the possible contamination of this biomaterial with viruses and prions, the latter related with neurodegenerative diseases such as bovine spongiform encephalopathy. Collagen is difficult to obtain due to its limited sources and can be degraded easily, which is a handicap if a prolonged neurotherapeutic effect is needed. PLGA degrades into by-products that might exacerbate inflammation, therefore producing additional brain damage after brain injury [244,245]. In the case of chitosan, this biomaterial shows fast degradation and some preparations cause allergic reactions due to residual components [246]. Matrigel, a solubilized mix of ECM proteins extracted from the Englebreth-Holm-Swarm mouse sarcoma, is not adequate for clinical application despite the proven experimental therapeutic potential of nSCs embedded in this material to enhance post-stroke functional improvement [135]. Fibrin hydrogels might support cells adhesion and growth; however, the poor stiffness, fast degradation, and shrinkage of this biomaterial represent a limitation for the clinics. In this context, silk fibroin constitutes an interesting biomaterial for stem cells/factors therapy in brain injuries and neurodegenerative diseases. This flexible and adaptable biomaterial has been used for years in a variety of biomedical applications [247,248]. We have recently developed an in situ fast-gelling silk fibroin hydrogel through the sonication-induced of regenerated silk fibroin solutions [188]. This hydrogel, with elastic modulus in the range of 6-30 kPa [188], favors stem cell survival in vitro and in vivo (Figure 4) [249] and can be injected in the brain tissue without causing significant inflammatory or neural death responses in an interval of four weeks of analysis [188]. In our specific study, after brain-silk-fibroin transplantation, we did not find impairments of sensorimotor and cognitive capacities or sleep-wake disturbances [188]. However, we do not have any evidence regarding whether this silk fibroin biomaterial might be therapeutically more efficient than other alternative biomaterials. From our point of view, in terms of clinical applicability, the in vivo biocompatibility of different materials with brain tissue should not be checked exclusively by the examination of tissular inflammatory or cytotoxicity responses without addressing important aspects of brain functionality. For example, it would be widely recommended to perform animal behavioral testing to examine possible sensorimotor, memory, and learning abnormalities as a consequence of the biomaterial implantation or even to further the study of structural and functional connectivity by using anatomic tracers, electrophysiology, and brain imaging-based approaches [188,235]. In contrast, there are also a very limited number of studies comparing the in vivo toxicity of different biomaterials as well as the therapeutic efficacy under the same brain damage models. In this context one would expect a comparison between different biomaterial candidates which are under study for brain repair following brain damage. However, no sufficient effort has been made in this sense creating a lack of consensus with respect to which biomaterials look most promising. In one in vitro study it was found that nSCs migration, proliferation and differentiation were better supported by laminin matrices and Matrigel than fibronectin or poly-L-ornithine [250]. In other example, a comparison between different HA and PEG hydrogel formulations was undertaken to examine the survival, growth and differentiation of neural progenitor cells [251]. We do not have enough information regarding both the optimal site of cerebral implantation and temporal point of intervention to achieve the best cell-biomaterial engraftment/therapeutic effect compromise after brain injury. Post-stroke recovery has been largely demonstrated in a majority of studies implanting cells and biomaterials but functional outcome was evaluated with different readouts and distinct brain damage models being unknown which therapeutic conditions might be more favorable [56]. In most cases, the molecular and 
cellular mechanisms responsible for recovery after brain cell transplantation have not been completely elucidated. Regarding the action mechanisms of SCs a nice contribution has been recently made by Wang et al. They demonstrated how sensorimotor recovery after stroke was due to the structural and functional integration of transplanted nSCs with the host brain circuitry examined by voltage-sensitive dye imaging and anatomic tracers [8].

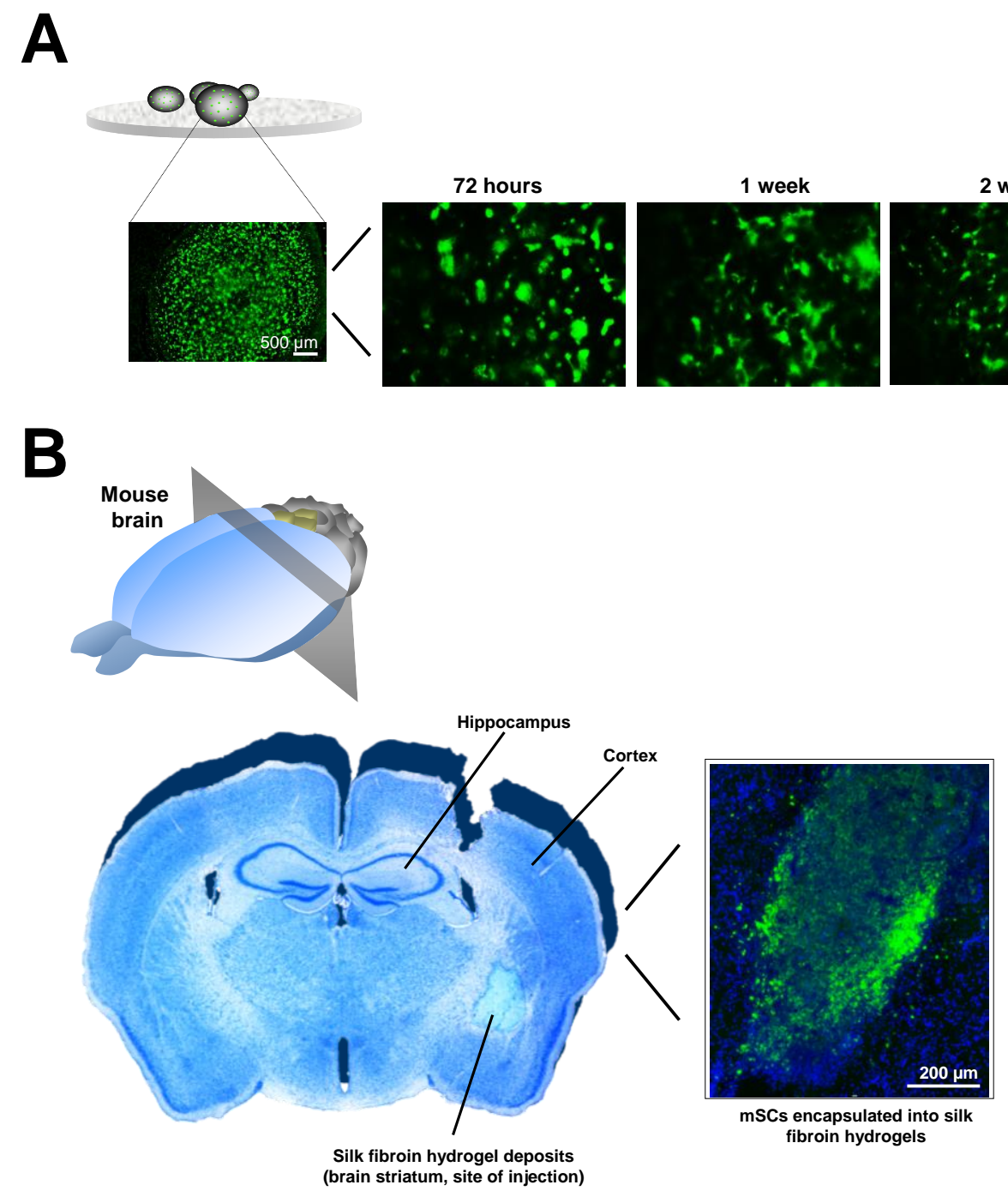

Figure 4. Stem cell engraftment assisted by silk fibroin-based hydrogels. (A) Positive staining for calcein (vital dye) showing how a specific stem cell population of mesenchymal origin (mSCs) survives in vitro integrated into silk fibroin hydrogel droplets during a two-week study period. (B) In vivo mSCs engraftment in the mouse brain is enhanced by the inclusion of this cell population into silk fibroin hydrogels [249]. Implantation of mSCs expressing the Enhanced Green Fluorescent Protein (EGFP) was done in the brain striatum of non-EGFP mice. In the figure, nuclei were stained with Hoechst (pseudocolor blue). It is known that the EGFP antigen might trigger an immunological response causing the loss of EGFP-cells in a non-EGFP brain microenvironment. However, the small pore size of silk hydrogels ( 100-200 nm) seems to constitute a barrier to attenuate the immuno-attack of resident immune cells against the transplanted EGFP-mSCs. This barrier may also contribute to isolate and protect the engrafted mSCs from a hostile microenvironment as is the brain tissue after injury. Thus, this silk fibroin hydrogel favors the retention and survival of mSCs in the brain striatum for up to four weeks after transplantation (period examined in the image shown), a time frame that goes beyond the lifespan seen with different types of SCs engrafted without a biomaterial scaffold. 


\section{Concluding Remarks}

Cures for stroke and other CNS injuries through engineered biomaterials will have a major positive impact in heavy and long-term burdens on patients and healthcare systems. The development of advanced biomaterials for cerebral damage responds to a major clinical need to provide patients with an efficient technological solution. Across the last two decades of experimental research, it has been possible to partially restore functionality loss after brain injury by using biomaterials of different composition and format to favor the engraftment of cells with neuro-therapeutic abilities. Despite the valuable contribution of behavioral studies in examining the improvement of functional outcomes in animals, in many cases, the molecular and cellular substrates underlying recovery are unknown, making it necessary to further investigate these mechanisms to rationally identify those targets whose modulation through cells and biomaterials might lead to greater therapeutic benefit. In addition, it would also be ideal to advance the screening of those more promising biomaterials such as those that are poorly inmmunogenic and less cytotoxic with controlled stiffness properties to facilitate their integration with the brain tissue through minimally invasive procedures. Tolerability of hydrogels should be examined using a multidimensional approach that could initially include preliminary in vitro studies, and the subsequent implantation in animals to analyze the in vivo bio-response at both the structural and functional level. It is also essential to examine concerns regarding the best temporal point of intervention and site of implantation to achieve an efficient post-brain-damage therapeutic response.

Although cerebral implantation of biomaterials-based hydrogels has not been applied in human subjects after brain injury, the antecedents presented in the preclinical (stem cells plus biomaterials) and clinical (stem cells) scenarios outline a magnificent opportunity for the treatment of CNS disorders using distinct biomaterials. In recent years, the fast evolution of this field predisposes the continuation of the search, characterization, and improvement of advanced hydrogels to clinical translation.

Acknowledgments: The authors apologize to colleagues whose important work was not directly cited due to space limitations. We express our gratitude to Masaru Okabe (Osaka University, Japan) and Jose Carlos Segovia (CIEMAT, Madrid, Spain) who donated to us the C57BL/6-Tg(CAG-EGFP)C14-Y01-FM131Osb mice for intracerebral transplantation of mSCs expressing EGFP. This study was supported by the community of Madrid (grant Neurocentro-B2017/BMD-3760) and funds from the Spanish Ministry of Economy and Competitiveness (MAT2016-79832-R and MAT2015-66666-C3-3-R).

Conflicts of Interest: The authors declare no conflict of interest.

\section{References}

1. Boltze, J.; Arnold, A.; Walczak, P.; Jolkkonen, J.; Cui, L.; Wagner, D.C. The Dark Side of the Force-Constraints and Complications of Cell Therapies for Stroke. Front. Neurol. 2015, 6, 155. [CrossRef] [PubMed]

2. Bao, X.; Feng, M.; Wei, J.; Han, Q.; Zhao, H.; Li, G.; Zhu, Z.; Xing, H.; An, Y.; Qin, C.; et al. Transplantation of Flk-1+ human bone marrow-derived mesenchymal stem cells promotes angiogenesis and neurogenesis after cerebral ischemia in rats. Eur. J. Neurosci. 2011, 34, 87-98. [CrossRef] [PubMed]

3. Andres, R.H.; Horie, N.; Slikker, W.; Keren-Gill, H.; Zhan, K.; Sun, G.; Manley, N.C.; Pereira, M.P.; Sheikh, L.A.; McMillan, E.L.; et al. Human neural stem cells enhance structural plasticity and axonal transport in the ischaemic brain. Brain 2011, 134, 1777-1789. [CrossRef] [PubMed]

4. Darsalia, V.; Kallur, T.; Kokaia, Z. Survival, migration and neuronal differentiation of human fetal striatal and cortical neural stem cells grafted in stroke-damaged rat striatum. Eur. J. Neurosci. 2007, 26, 605-614. [CrossRef] [PubMed]

5. Kelly, S.; Bliss, T.M.; Shah, A.K.; Sun, G.H.; Ma, M.; Foo, W.C.; Masel, J.; Yenari, M.A.; Weissman, I.L.; Uchida, N.; et al. Transplanted human fetal neural stem cells survive, migrate, and differentiate in ischemic rat cerebral cortex. Proc. Natl. Acad. Sci. USA 2004, 101, 11839-11844. [CrossRef] [PubMed]

6. Mora-Lee, S.; Sirerol-Piquer, M.S.; Gutierrez-Perez, M.; Gomez-Pinedo, U.; Roobrouck, V.D.; Lopez, T.; Casado-Nieto, M.; Abizanda, G.; Rabena, M.T.; Verfaille, C.; et al. Therapeutic effects of hMAPC and hMSC transplantation after stroke in mice. PLoS ONE 2012, 7, e43683. [CrossRef] [PubMed] 
7. Tuladhar, A.; Morshead, C.M.; Shoichet, M.S. Circumventing the blood-brain barrier: Local delivery of cyclosporin A stimulates stem cells in stroke-injured rat brain. J. Control. Release 2015, 215, 1-11. [CrossRef] [PubMed]

8. Wang, Y.; Zhao, Z.; Rege, S.V.; Wang, M.; Si, G.; Zhou, Y.; Wang, S.; Griffin, J.H.; Goldman, S.A.; Zlokovic, B.V. 3K3A-activated protein $\mathrm{C}$ stimulates postischemic neuronal repair by human neural stem cells in mice. Nat. Med. 2016, 22, 1050-1055. [CrossRef] [PubMed]

9. Hoag, H. Drug delivery: Brain food. Nature 2014, 510, S6-S7. [CrossRef] [PubMed]

10. Benjamin, E.J.; Blaha, M.J.; Chiuve, S.E.; Cushman, M.; Das, S.R.; Deo, R.; de Ferranti, S.D.; Floyd, J.; Fornage, M.; Gillespie, C.; et al. Heart Disease and Stroke Statistics-2017 Update: A Report From the American Heart Association. Circulation 2017, 135, e146-e603. [CrossRef] [PubMed]

11. Cooke, M.J.; Vulicb, K.; Shoichet, M.S. Design of biomaterials to enhance stem cell survival when transplanted into the damaged central nervous system. Soft Matter 2010, 6, 4988-4998. [CrossRef]

12. Khaing, Z.Z.; Thomas, R.C.; Geissler, S.A.; Schmidt, C.E. Advanced biomaterials for repairing the nervous system: What can hydrogels do for the brain? Materialstoday 2014, 17, 332-340. [CrossRef]

13. Lim, T.C.; Spector, M. Biomaterials for Enhancing CNS Repair. Transl. Stroke Res. 2017, 8, 57-64. [CrossRef] [PubMed]

14. Orive, G.; Anitua, E.; Pedraz, J.L.; Emerich, D.F. Biomaterials for promoting brain protection, repair and regeneration. Nat. Rev. Neurosci. 2009, 10, 682-692. [CrossRef] [PubMed]

15. GBD-2013-study. Global, regional, and national age-sex specific all-cause and cause-specific mortality for 240 causes of death, 1990-2013: A systematic analysis for the Global Burden of Disease Study 2013. Lancet 2015, 385, 117-171. [CrossRef]

16. O'Mahony, P.G.; Thomson, R.G.; Dobson, R.; Rodgers, H.; James, O.F. The prevalence of stroke and associated disability. J. Public Health Med. 1999, 21, 166-171. [CrossRef] [PubMed]

17. Krishnamurthi, R.V.; Feigin, V.L.; Forouzanfar, M.H.; Mensah, G.A.; Connor, M.; Bennett, D.A.; Moran, A.E.; Sacco, R.L.; Anderson, L.M.; Truelsen, T.; et al. Global and regional burden of first-ever ischaemic and haemorrhagic stroke during 1990-2010: Findings from the Global Burden of Disease Study 2010. Lancet Glob. Health 2013, 1, e259-e281. [CrossRef]

18. Smajlovic, D. Strokes in young adults: Epidemiology and prevention. Vasc. Health Risk Manag. 2015, 11, 157-164. [CrossRef] [PubMed]

19. Brott, T.; Bogousslavsky, J. Treatment of acute ischemic stroke. N. Engl. J. Med. 2000, 343, 710-722. [CrossRef] [PubMed]

20. Hankey, G.J. Stroke. Lancet 2017, 389, 641-654. [CrossRef]

21. Campbell, B.C.; Mitchell, P.J. Endovascular therapy for ischemic stroke. N. Engl. J. Med. 2015, 372, $2365-2366$. [CrossRef] [PubMed]

22. Goyal, M.; Menon, B.K.; van Zwam, W.H.; Dippel, D.W.; Mitchell, P.J.; Demchuk, A.M.; Davalos, A.; Majoie, C.B.; van der Lugt, A.; de Miquel, M.A.; et al. Endovascular thrombectomy after large-vessel ischaemic stroke: A meta-analysis of individual patient data from five randomised trials. Lancet 2016, 387, 1723-1731. [CrossRef]

23. Saver, J.L.; Goyal, M.; Bonafe, A.; Diener, H.C.; Levy, E.I.; Pereira, V.M.; Albers, G.W.; Cognard, C.; Cohen, D.J.; Hacke, W.; et al. Stent-retriever thrombectomy after intravenous t-PA vs. t-PA alone in stroke. N. Engl. J. Med. 2015, 372, 2285-2295. [CrossRef] [PubMed]

24. Emberson, J.; Lees, K.R.; Lyden, P.; Blackwell, L.; Albers, G.; Bluhmki, E.; Brott, T.; Cohen, G.; Davis, S.; Donnan, G.; et al. Effect of treatment delay, age, and stroke severity on the effects of intravenous thrombolysis with alteplase for acute ischaemic stroke: A meta-analysis of individual patient data from randomised trials. Lancet 2014, 384, 1929-1935. [CrossRef]

25. George, P.M.; Steinberg, G.K. Novel Stroke Therapeutics: Unraveling Stroke Pathophysiology and Its Impact on Clinical Treatments. Neuron 2015, 87, 297-309. [CrossRef] [PubMed]

26. Corbetta, D.; Imeri, F.; Gatti, R. Rehabilitation that incorporates virtual reality is more effective than standard rehabilitation for improving walking speed, balance and mobility after stroke: A systematic review. J. Physiother. 2015, 61, 117-124. [CrossRef] [PubMed]

27. Laver, K.E.; George, S.; Thomas, S.; Deutsch, J.E.; Crotty, M. Virtual reality for stroke rehabilitation. Cochrane Database Syst. Rev. 2015, CD008349. [CrossRef] [PubMed] 
28. Levy, R.; Ruland, S.; Weinand, M.; Lowry, D.; Dafer, R.; Bakay, R. Cortical stimulation for the rehabilitation of patients with hemiparetic stroke: A multicenter feasibility study of safety and efficacy. J. Neurosurg. 2008, 108, 707-714. [CrossRef] [PubMed]

29. Levy, R.M.; Harvey, R.L.; Kissela, B.M.; Winstein, C.J.; Lutsep, H.L.; Parrish, T.B.; Cramer, S.C.; Venkatesan, L. Epidural Electrical Stimulation for Stroke Rehabilitation: Results of the Prospective, Multicenter, Randomized, Single-Blinded Everest Trial. Neurorehabil. Neural Repair 2016, 30, 107-119. [CrossRef] [PubMed]

30. Jaillard, A.; Martin, C.D.; Garambois, K.; Lebas, J.F.; Hommel, M. Vicarious function within the human primary motor cortex? A longitudinal fMRI stroke study. Brain 2005, 128, 1122-1138. [CrossRef] [PubMed]

31. Nudo, R.J.; Wise, B.M.; SiFuentes, F.; Milliken, G.W. Neural substrates for the effects of rehabilitative training on motor recovery after ischemic infarct. Science 1996, 272, 1791-1794. [CrossRef] [PubMed]

32. Krucoff, M.O.; Rahimpour, S.; Slutzky, M.W.; Edgerton, V.R.; Turner, D.A. Enhancing Nervous System Recovery through Neurobiologics, Neural Interface Training, and Neurorehabilitation. Front. Neurosci. 2016, 10, 584. [CrossRef] [PubMed]

33. Borlongan, C.V.; Tajima, Y.; Trojanowski, J.Q.; Lee, V.M.; Sanberg, P.R. Transplantation of cryopreserved human embryonal carcinoma-derived neurons (NT2N cells) promotes functional recovery in ischemic rats. Exp. Neurol. 1998, 149, 310-321. [CrossRef] [PubMed]

34. Chen, J.; Li, Y.; Chopp, M. Intracerebral transplantation of bone marrow with BDNF after MCAo in rat. Neuropharmacology 2000, 39, 711-716. [CrossRef]

35. Chen, J.; Li, Y.; Wang, L.; Lu, M.; Zhang, X.; Chopp, M. Therapeutic benefit of intracerebral transplantation of bone marrow stromal cells after cerebral ischemia in rats. J. Neurol. Sci. 2001, 189, 49-57. [CrossRef]

36. Chen, J.; Li, Y.; Wang, L.; Zhang, Z.; Lu, D.; Lu, M.; Chopp, M. Therapeutic benefit of intravenous administration of bone marrow stromal cells after cerebral ischemia in rats. Stroke 2001, 32, 1005-1011. [CrossRef] [PubMed]

37. Li, Y.; Chopp, M.; Chen, J.; Wang, L.; Gautam, S.C.; Xu, Y.X.; Zhang, Z. Intrastriatal transplantation of bone marrow nonhematopoietic cells improves functional recovery after stroke in adult mice. J. Cereb. Blood Flow MeTable 2000, 20, 1311-1319. [CrossRef] [PubMed]

38. Bang, O.Y.; Lee, J.S.; Lee, P.H.; Lee, G. Autologous mesenchymal stem cell transplantation in stroke patients. Ann. Neurol. 2005, 57, 874-882. [CrossRef] [PubMed]

39. Borlongan, C.V. Preliminary Reports of Stereotaxic Stem Cell Transplants in Chronic Stroke Patients. Mol. Ther. 2016, 24, 1710-1711. [CrossRef] [PubMed]

40. Borlongan, C.V. Age of PISCES: Stem-cell clinical trials in stroke. Lancet 2016, 388, 736-738. [CrossRef]

41. Kondziolka, D.; Steinberg, G.K.; Wechsler, L.; Meltzer, C.C.; Elder, E.; Gebel, J.; Decesare, S.; Jovin, T.; Zafonte, R.; Lebowitz, J.; et al. Neurotransplantation for patients with subcortical motor stroke: A phase 2 randomized trial. J. Neurosurg. 2005, 103, 38-45. [CrossRef] [PubMed]

42. Kondziolka, D.; Wechsler, L.; Goldstein, S.; Meltzer, C.; Thulborn, K.R.; Gebel, J.; Jannetta, P.; DeCesare, S.; Elder, E.M.; McGrogan, M.; et al. Transplantation of cultured human neuronal cells for patients with stroke. Neurology 2000, 55, 565-569. [CrossRef] [PubMed]

43. Kordower, J.H.; Freeman, T.B.; Snow, B.J.; Vingerhoets, F.J.; Mufson, E.J.; Sanberg, P.R.; Hauser, R.A.; Smith, D.A.; Nauert, G.M.; Perl, D.P.; et al. Neuropathological evidence of graft survival and striatal reinnervation after the transplantation of fetal mesencephalic tissue in a patient with Parkinson's disease. N. Engl. J. Med. 1995, 332, 1118-1124. [CrossRef] [PubMed]

44. Lee, J.S.; Hong, J.M.; Moon, G.J.; Lee, P.H.; Ahn, Y.H.; Bang, O.Y. A long-term follow-up study of intravenous autologous mesenchymal stem cell transplantation in patients with ischemic stroke. Stem Cells 2010, 28, 1099-1106. [CrossRef] [PubMed]

45. Lindvall, O.; Sawle, G.; Widner, H.; Rothwell, J.C.; Bjorklund, A.; Brooks, D.; Brundin, P.; Frackowiak, R.; Marsden, C.D.; Odin, P.; et al. Evidence for long-term survival and function of dopaminergic grafts in progressive Parkinson's disease. Ann. Neurol. 1994, 35, 172-180. [CrossRef] [PubMed]

46. Savitz, S.I.; Dinsmore, J.; Wu, J.; Henderson, G.V.; Stieg, P.; Caplan, L.R. Neurotransplantation of fetal porcine cells in patients with basal ganglia infarcts: A preliminary safety and feasibility study. Cerebrovasc. Dis. 2005, 20, 101-107. [CrossRef] [PubMed] 
47. Steinberg, G.K.; Kondziolka, D.; Wechsler, L.R.; Lunsford, L.D.; Coburn, M.L.; Billigen, J.B.; Kim, A.S.; Johnson, J.N.; Bates, D.; King, B.; et al. Clinical Outcomes of Transplanted Modified Bone Marrow-Derived Mesenchymal Stem Cells in Stroke: A Phase 1/2a Study. Stroke 2016, 47, 1817-1824. [CrossRef] [PubMed]

48. Jacobson, L.O.; Simmons, E.L.; Marks, E.K.; Eldredge, J.H. Recovery from radiation injury. Science 1951, 113, 510-511. [CrossRef] [PubMed]

49. Lorenz, E.; Uphoff, D.; Reid, T.R.; Shelton, E. Modification of irradiation injury in mice and guinea pigs by bone marrow injections. J. Natl. Cancer Inst. 1951, 12, 197-201. [CrossRef] [PubMed]

50. Thomas, E.D.; Lochte, H.L., Jr.; Lu, W.C.; Ferrebee, J.W. Intravenous infusion of bone marrow in patients receiving radiation and chemotherapy. N. Engl. J. Med. 1957, 257, 491-496. [CrossRef] [PubMed]

51. Rama, P.; Matuska, S.; Paganoni, G.; Spinelli, A.; De Luca, M.; Pellegrini, G. Limbal stem-cell therapy and long-term corneal regeneration. N. Engl. J. Med. 2010, 363, 147-155. [CrossRef] [PubMed]

52. Panes, J. Stem Cell Therapy for Perianal Fistulas in Crohn's Disease. Gastroenterol Hepatol (N.Y.) 2016, 12, 637-640.

53. Hirsch, T.; Rothoeft, T.; Teig, N.; Bauer, J.W.; Pellegrini, G.; De Rosa, L.; Scaglione, D.; Reichelt, J.; Klausegger, A.; Kneisz, D.; et al. Regeneration of the entire human epidermis using transgenic stem cells. Nature 2017, 551, 327-332. [CrossRef] [PubMed]

54. Trounson, A.; McDonald, C. Stem Cell Therapies in Clinical Trials: Progress and Challenges. Cell Stem Cell 2015, 17, 11-22. [CrossRef] [PubMed]

55. Abou-El-Enein, M.; Elsanhoury, A.; Reinke, P. Overcoming Challenges Facing Advanced Therapies in the EU Market. Cell Stem Cell 2016, 19, 293-297. [CrossRef] [PubMed]

56. Khalil, D.N.; Smith, E.L.; Brentjens, R.J.; Wolchok, J.D. The future of cancer treatment: Immunomodulation, CARs and combination immunotherapy. Nat. Rev. Clin. Oncol. 2016, 13, 273-290. [CrossRef] [PubMed]

57. Gervois, P.; Wolfs, E.; Ratajczak, J.; Dillen, Y.; Vangansewinkel, T.; Hilkens, P.; Bronckaers, A.; Lambrichts, I.; Struys, T. Stem Cell-Based Therapies for Ischemic Stroke: Preclinical Results and the Potential of Imaging-Assisted Evaluation of Donor Cell Fate and Mechanisms of Brain Regeneration. Med. Res. Rev. 2016, 36, 1080-1126. [CrossRef] [PubMed]

58. Lees, J.S.; Sena, E.S.; Egan, K.J.; Antonic, A.; Koblar, S.A.; Howells, D.W.; Macleod, M.R. Stem cell-based therapy for experimental stroke: A systematic review and meta-analysis. Int. J. Stroke 2012, 7, 582-588. [CrossRef] [PubMed]

59. Bernstock, J.D.; Peruzzotti-Jametti, L.; Ye, D.; Gessler, F.A.; Maric, D.; Vicario, N.; Lee, Y.J.; Pluchino, S.; Hallenbeck, J.M. Neural stem cell transplantation in ischemic stroke: A role for preconditioning and cellular engineering. J. Cereb. Blood Flow MeTable 2017, 37, 2314-2319. [CrossRef] [PubMed]

60. Dirnagl, U.; Iadecola, C.; Moskowitz, M.A. Pathobiology of ischaemic stroke: An integrated view. Trends Neurosci. 1999, 22, 391-397. [CrossRef]

61. Ramos-Cabrer, P.; Justicia, C.; Wiedermann, D.; Hoehn, M. Stem cell mediation of functional recovery after stroke in the rat. PLoS ONE 2010, 5, e12779. [CrossRef] [PubMed]

62. Taguchi, A.; Soma, T.; Tanaka, H.; Kanda, T.; Nishimura, H.; Yoshikawa, H.; Tsukamoto, Y.; Iso, H.; Fujimori, Y.; Stern, D.M.; et al. Administration of CD34+ cells after stroke enhances neurogenesis via angiogenesis in a mouse model. J. Clin. Invest. 2004, 114, 330-338. [CrossRef] [PubMed]

63. Astrup, J.; Symon, L.; Branston, N.M.; Lassen, N.A. Cortical evoked potential and extracellular K+ and H+ at critical levels of brain ischemia. Stroke 1977, 8, 51-57. [CrossRef] [PubMed]

64. Murphy, T.H.; Corbett, D. Plasticity during stroke recovery: From synapse to behaviour. Nat. Rev. Neurosci. 2009, 10, 861-872. [CrossRef] [PubMed]

65. Rallu, M.; Corbin, J.G.; Fishell, G. Parsing the prosencephalon. Nat. Rev. Neurosci. 2002, 3, 943-951. [CrossRef] [PubMed]

66. Kaneko, N.; Sawada, M.; Sawamoto, K. Mechanisms of neuronal migration in the adult brain. J. Neurochem. 2017, 141, 835-847. [CrossRef] [PubMed]

67. Obernier, K.; Cebrian-Silla, A.; Thomson, M.; Parraguez, J.I.; Anderson, R.; Guinto, C.; Rodas Rodriguez, J.; Garcia-Verdugo, J.M.; Alvarez-Buylla, A. Adult Neurogenesis Is Sustained by Symmetric Self-Renewal and Differentiation. Cell Stem Cell 2018, 22, 221-234. [CrossRef] [PubMed]

68. Arvidsson, A.; Collin, T.; Kirik, D.; Kokaia, Z.; Lindvall, O. Neuronal replacement from endogenous precursors in the adult brain after stroke. Nat. Med. 2002, 8, 963-970. [CrossRef] [PubMed] 
69. Reumers, V.; Deroose, C.M.; Krylyshkina, O.; Nuyts, J.; Geraerts, M.; Mortelmans, L.; Gijsbers, R.; Van den Haute, C.; Debyser, Z.; Baekelandt, V. Noninvasive and quantitative monitoring of adult neuronal stem cell migration in mouse brain using bioluminescence imaging. Stem Cells 2008, 26, 2382-2390. [CrossRef] [PubMed]

70. Chu, K.; Kim, M.; Park, K.I.; Jeong, S.W.; Park, H.K.; Jung, K.H.; Lee, S.T.; Kang, L.; Lee, K.; Park, D.K.; et al. Human neural stem cells improve sensorimotor deficits in the adult rat brain with experimental focal ischemia. Brain Res. 2004, 1016, 145-153. [CrossRef] [PubMed]

71. Riess, P.; Zhang, C.; Saatman, K.E.; Laurer, H.L.; Longhi, L.G.; Raghupathi, R.; Lenzlinger, P.M.; Lifshitz, J.; Boockvar, J.; Neugebauer, E.; et al. Transplanted neural stem cells survive, differentiate, and improve neurological motor function after experimental traumatic brain injury. Neurosurgery 2002, 51, 1043-1052, discussion 1043-1052. [CrossRef] [PubMed]

72. Zhu, J.M.; Zhao, Y.Y.; Chen, S.D.; Zhang, W.H.; Lou, L.; Jin, X. Functional recovery after transplantation of neural stem cells modified by brain-derived neurotrophic factor in rats with cerebral ischaemia. J. Int. Med. Res. 2011, 39, 488-498. [CrossRef] [PubMed]

73. Hattiangady, B.; Shuai, B.; Cai, J.; Coksaygan, T.; Rao, M.S.; Shetty, A.K. Increased dentate neurogenesis after grafting of glial restricted progenitors or neural stem cells in the aging hippocampus. Stem Cells 2007, 25, 2104-2117. [CrossRef] [PubMed]

74. Augestad, I.L.; Nyman, A.K.G.; Costa, A.I.; Barnett, S.C.; Sandvig, A.; Haberg, A.K.; Sandvig, I. Effects of Neural Stem Cell and Olfactory Ensheathing Cell Co-transplants on Tissue Remodelling After Transient Focal Cerebral Ischemia in the Adult Rat. Neurochem. Res. 2017, 42, 1599-1609. [CrossRef] [PubMed]

75. Harms, K.M.; Li, L.; Cunningham, L.A. Murine neural stem/progenitor cells protect neurons against ischemia by HIF-1alpha-regulated VEGF signaling. PLoS ONE 2010, 5, e9767. [CrossRef] [PubMed]

76. Roitbak, T.; Li, L.; Cunningham, L.A. Neural stem/progenitor cells promote endothelial cell morphogenesis and protect endothelial cells against ischemia via HIF-1alpha-regulated VEGF signaling. J. Cereb. Blood Flow MeTable 2008, 28, 1530-1542. [CrossRef] [PubMed]

77. Bliss, T.; Guzman, R.; Daadi, M.; Steinberg, G.K. Cell transplantation therapy for stroke. Stroke 2007, 38, 817-826. [CrossRef] [PubMed]

78. Goldman, S.A. Stem and Progenitor Cell-Based Therapy of the Central Nervous System: Hopes, Hype, and Wishful Thinking. Cell Stem Cell 2016, 18, 174-188. [CrossRef] [PubMed]

79. Wei, L.; Cui, L.; Snider, B.J.; Rivkin, M.; Yu, S.S.; Lee, C.S.; Adams, L.D.; Gottlieb, D.I.; Johnson, E.M., Jr.; $\mathrm{Yu}$, S.P.; et al. Transplantation of embryonic stem cells overexpressing Bcl-2 promotes functional recovery after transient cerebral ischemia. Neurobiol. Dis. 2005, 19, 183-193. [CrossRef] [PubMed]

80. Yanagisawa, D.; Qi, M.; Kim, D.H.; Kitamura, Y.; Inden, M.; Tsuchiya, D.; Takata, K.; Taniguchi, T.; Yoshimoto, K.; Shimohama, S.; et al. Improvement of focal ischemia-induced rat dopaminergic dysfunction by striatal transplantation of mouse embryonic stem cells. Neurosci. Lett. 2006, 407, 74-79. [CrossRef] [PubMed]

81. Thomson, J.A.; Itskovitz-Eldor, J.; Shapiro, S.S.; Waknitz, M.A.; Swiergiel, J.J.; Marshall, V.S.; Jones, J.M. Embryonic stem cell lines derived from human blastocysts. Science 1998, 282, 1145-1147. [CrossRef] [PubMed]

82. Solter, D. From teratocarcinomas to embryonic stem cells and beyond: A history of embryonic stem cell research. Nat. Rev. Genet. 2006, 7, 319-327. [CrossRef] [PubMed]

83. Honmou, O.; Onodera, R.; Sasaki, M.; Waxman, S.G.; Kocsis, J.D. Mesenchymal stem cells: Therapeutic outlook for stroke. Trends Mol. Med. 2012, 18, 292-297. [CrossRef] [PubMed]

84. Janowski, M.; Walczak, P.; Date, I. Intravenous route of cell delivery for treatment of neurological disorders: A meta-analysis of preclinical results. Stem Cells Dev. 2010, 19, 5-16. [CrossRef] [PubMed]

85. Li, Y.; Chopp, M. Marrow stromal cell transplantation in stroke and traumatic brain injury. Neurosci. Lett. 2009, 456, 120-123. [CrossRef] [PubMed]

86. Li, L.; Chao, J.; Shi, Y. Modeling neurological diseases using iPSC-derived neural cells : IPSC modeling of neurological diseases. Cell Tissue Res. 2017, 371, 143-151. [CrossRef] [PubMed]

87. Seki, T.; Yuasa, S.; Oda, M.; Egashira, T.; Yae, K.; Kusumoto, D.; Nakata, H.; Tohyama, S.; Hashimoto, H.; Kodaira, M.; et al. Generation of induced pluripotent stem cells from human terminally differentiated circulating T cells. Cell Stem Cell 2010, 7, 11-14. [CrossRef] [PubMed] 
88. Takahashi, K.; Yamanaka, S. Induction of pluripotent stem cells from mouse embryonic and adult fibroblast cultures by defined factors. Cell 2006, 126, 663-676. [CrossRef] [PubMed]

89. Tat, P.A.; Sumer, H.; Jones, K.L.; Upton, K.; Verma, P.J. The efficient generation of induced pluripotent stem (iPS) cells from adult mouse adipose tissue-derived and neural stem cells. Cell Transplant. 2010, 19, 525-536. [CrossRef] [PubMed]

90. Chen, S.J.; Chang, C.M.; Tsai, S.K.; Chang, Y.L.; Chou, S.J.; Huang, S.S.; Tai, L.K.; Chen, Y.C.; Ku, H.H.; Li, H.Y.; et al. Functional improvement of focal cerebral ischemia injury by subdural transplantation of induced pluripotent stem cells with fibrin glue. Stem. Cells Dev. 2010, 19, 1757-1767. [CrossRef] [PubMed]

91. Jiang, M.; Lv, L.; Ji, H.; Yang, X.; Zhu, W.; Cai, L.; Gu, X.; Chai, C.; Huang, S.; Sun, J.; et al. Induction of pluripotent stem cells transplantation therapy for ischemic stroke. Mol. Cell Biochem. 2011, 354, 67-75. [CrossRef] [PubMed]

92. Yuan, T.; Liao, W.; Feng, N.H.; Lou, Y.L.; Niu, X.; Zhang, A.J.; Wang, Y.; Deng, Z.F. Human induced pluripotent stem cell-derived neural stem cells survive, migrate, differentiate, and improve neurologic function in a rat model of middle cerebral artery occlusion. Stem Cell Res. Ther. 2013, 4, 73. [CrossRef] [PubMed]

93. Kawai, H.; Yamashita, T.; Ohta, Y.; Deguchi, K.; Nagotani, S.; Zhang, X.; Ikeda, Y.; Matsuura, T.; Abe, K. Tridermal tumorigenesis of induced pluripotent stem cells transplanted in ischemic brain. J. Cereb. Blood Flow MeTable 2010, 30, 1487-1493. [CrossRef] [PubMed]

94. Lamm, N.; Ben-David, U.; Golan-Lev, T.; Storchova, Z.; Benvenisty, N.; Kerem, B. Genomic Instability in Human Pluripotent Stem Cells Arises from Replicative Stress and Chromosome Condensation Defects. Cell Stem Cell 2016, 18, 253-261. [CrossRef] [PubMed]

95. Lister, R.; Pelizzola, M.; Kida, Y.S.; Hawkins, R.D.; Nery, J.R.; Hon, G.; Antosiewicz-Bourget, J.; O’Malley, R.; Castanon, R.; Klugman, S.; et al. Hotspots of aberrant epigenomic reprogramming in human induced pluripotent stem cells. Nature 2011, 471, 68-73. [CrossRef] [PubMed]

96. Nakano-Doi, A.; Nakagomi, T.; Fujikawa, M.; Nakagomi, N.; Kubo, S.; Lu, S.; Yoshikawa, H.; Soma, T.; Taguchi, A.; Matsuyama, T. Bone marrow mononuclear cells promote proliferation of endogenous neural stem cells through vascular niches after cerebral infarction. Stem Cells 2010, 28, 1292-1302. [CrossRef] [PubMed]

97. Shyu, W.C.; Lin, S.Z.; Chiang, M.F.; Su, C.Y.; Li, H. Intracerebral peripheral blood stem cell (CD34+) implantation induces neuroplasticity by enhancing beta1 integrin-mediated angiogenesis in chronic stroke rats. J. Neurosci. 2006, 26, 3444-3453. [CrossRef] [PubMed]

98. Friedenstein, A.J.; Chailakhjan, R.K.; Lalykina, K.S. The development of fibroblast colonies in monolayer cultures of guinea-pig bone marrow and spleen cells. Cell Tissue Kinet. 1970, 3, 393-403. [CrossRef] [PubMed]

99. Bianco, P. “Mesenchymal” stem cells. Annu. Rev. Cell Dev. Biol. 2014, 30, 677-704. [CrossRef] [PubMed]

100. Gonzalez-Nieto, D.; Li, L.; Kohler, A.; Ghiaur, G.; Ishikawa, E.; Sengupta, A.; Madhu, M.; Arnett, J.L.; Santho, R.A.; Dunn, S.K.; et al. Connexin-43 in the osteogenic BM niche regulates its cellular composition and the bidirectional traffic of hematopoietic stem cells and progenitors. Blood 2012, 119, 5144-5154. [CrossRef] [PubMed]

101. Mendez-Ferrer, S.; Michurina, T.V.; Ferraro, F.; Mazloom, A.R.; Macarthur, B.D.; Lira, S.A.; Scadden, D.T.; Ma'ayan, A.; Enikolopov, G.N.; Frenette, P.S. Mesenchymal and haematopoietic stem cells form a unique bone marrow niche. Nature. 2010, 466, 829-834. [CrossRef] [PubMed]

102. Chen, J.; Zhang, Z.G.; Li, Y.; Wang, L.; Xu, Y.X.; Gautam, S.C.; Lu, M.; Zhu, Z.; Chopp, M. Intravenous administration of human bone marrow stromal cells induces angiogenesis in the ischemic boundary zone after stroke in rats. Circ. Res. 2003, 92, 692-699. [CrossRef] [PubMed]

103. Horie, N.; Pereira, M.P.; Niizuma, K.; Sun, G.; Keren-Gill, H.; Encarnacion, A.; Shamloo, M.; Hamilton, S.A.; Jiang, K.; Huhn, S.; et al. Transplanted stem cell-secreted vascular endothelial growth factor effects poststroke recovery, inflammation, and vascular repair. Stem Cells 2011, 29, 274-285. [CrossRef] [PubMed]

104. Ishizaka, S.; Horie, N.; Satoh, K.; Fukuda, Y.; Nishida, N.; Nagata, I. Intra-arterial cell transplantation provides timing-dependent cell distribution and functional recovery after stroke. Stroke 2013, 44, 720-726. [CrossRef] [PubMed]

105. Li, G.; Yu, F.; Lei, T.; Gao, H.; Li, P.; Sun, Y.; Huang, H.; Mu, Q. Bone marrow mesenchymal stem cell therapy in ischemic stroke: Mechanisms of action and treatment optimization strategies. Neural Regen. Res. 2016, 11, 1015-1024. [CrossRef] [PubMed] 
106. Li, Y.; Chen, J.; Chopp, M. Adult bone marrow transplantation after stroke in adult rats. Cell Transplant. 2001, 10, 31-40. [CrossRef] [PubMed]

107. Scheibe, F.; Klein, O.; Klose, J.; Priller, J. Mesenchymal stromal cells rescue cortical neurons from apoptotic cell death in an in vitro model of cerebral ischemia. Cell Mol. Neurobiol. 2012, 32, 567-576. [CrossRef] [PubMed]

108. Scheibe, F.; Ladhoff, J.; Huck, J.; Grohmann, M.; Blazej, K.; Oersal, A.; Baeva, N.; Seifert, M.; Priller, J. Immune effects of mesenchymal stromal cells in experimental stroke. J. Cereb. Blood Flow MeTable 2012, 32, 1578-1588. [CrossRef] [PubMed]

109. Shinozuka, K.; Dailey, T.; Tajiri, N.; Ishikawa, H.; Kaneko, Y.; Borlongan, C.V. Stem cell transplantation for neuroprotection in stroke. Brain Sci. 2013, 3, 239-261. [CrossRef] [PubMed]

110. Kopen, G.C.; Prockop, D.J.; Phinney, D.G. Marrow stromal cells migrate throughout forebrain and cerebellum, and they differentiate into astrocytes after injection into neonatal mouse brains. Proc. Natl. Acad. Sci. USA 1999, 96, 10711-10716. [CrossRef] [PubMed]

111. Lepski, G.; Jannes, C.E.; Strauss, B.; Marie, S.K.; Nikkhah, G. Survival and neuronal differentiation of mesenchymal stem cells transplanted into the rodent brain are dependent upon microenvironment. Tissue Eng. Part A 2010, 16, 2769-2782. [CrossRef] [PubMed]

112. Alvarez-Dolado, M.; Pardal, R.; Garcia-Verdugo, J.M.; Fike, J.R.; Lee, H.O.; Pfeffer, K.; Lois, C.; Morrison, S.J.; Alvarez-Buylla, A. Fusion of bone-marrow-derived cells with Purkinje neurons, cardiomyocytes and hepatocytes. Nature 2003, 425, 968-973. [CrossRef] [PubMed]

113. Kokaia, Z.; Martino, G.; Schwartz, M.; Lindvall, O. Cross-talk between neural stem cells and immune cells: The key to better brain repair? Nat. Neurosci. 2012, 15, 1078-1087. [CrossRef] [PubMed]

114. Leu, S.; Lin, Y.C.; Yuen, C.M.; Yen, C.H.; Kao, Y.H.; Sun, C.K.; Yip, H.K. Adipose-derived mesenchymal stem cells markedly attenuate brain infarct size and improve neurological function in rats. J. Transl. Med. 2010, 8, 63. [CrossRef] [PubMed]

115. Meisel, R.; Zibert, A.; Laryea, M.; Gobel, U.; Daubener, W.; Dilloo, D. Human bone marrow stromal cells inhibit allogeneic T-cell responses by indoleamine 2,3-dioxygenase-mediated tryptophan degradation. Blood 2004, 103, 4619-4621. [CrossRef] [PubMed]

116. Zhu, Y.; Guan, Y.M.; Huang, H.L.; Wang, Q.S. Human umbilical cord blood mesenchymal stem cell transplantation suppresses inflammatory responses and neuronal apoptosis during early stage of focal cerebral ischemia in rabbits. Acta Pharmacol. Sin. 2014, 35, 585-591. [CrossRef] [PubMed]

117. Burns, T.C.; Verfaillie, C.M.; Low, W.C. Stem cells for ischemic brain injury: A critical review. J. Comp. Neurol. 2009, 515, 125-144. [CrossRef] [PubMed]

118. Hoehn, B.D.; Palmer, T.D.; Steinberg, G.K. Neurogenesis in rats after focal cerebral ischemia is enhanced by indomethacin. Stroke 2005, 36, 2718-2724. [CrossRef] [PubMed]

119. Hegyi, B.; Kornyei, Z.; Ferenczi, S.; Fekete, R.; Kudlik, G.; Kovacs, K.J.; Madarasz, E.; Uher, F. Regulation of mouse microglia activation and effector functions by bone marrow-derived mesenchymal stem cells. Stem Cells Dev. 2014, 23, 2600-2612. [CrossRef] [PubMed]

120. Tang, Y.; Le, W. Differential Roles of M1 and M2 Microglia in Neurodegenerative Diseases. Mol. Neurobiol. 2016, 53, 1181-1194. [CrossRef] [PubMed]

121. Li, Y.; Chen, J.; Zhang, C.L.; Wang, L.; Lu, D.; Katakowski, M.; Gao, Q.; Shen, L.H.; Zhang, J.; Lu, M.; et al. Gliosis and brain remodeling after treatment of stroke in rats with marrow stromal cells. Glia 2005, 49, 407-417. [CrossRef] [PubMed]

122. Hsuan, Y.C.; Lin, C.H.; Chang, C.P.; Lin, M.T. Mesenchymal stem cell-based treatments for stroke, neural trauma, and heat stroke. Brain Behav. 2016, 6, e00526. [CrossRef] [PubMed]

123. Wakabayashi, K.; Nagai, A.; Sheikh, A.M.; Shiota, Y.; Narantuya, D.; Watanabe, T.; Masuda, J.; Kobayashi, S.; Kim, S.U.; Yamaguchi, S. Transplantation of human mesenchymal stem cells promotes functional improvement and increased expression of neurotrophic factors in a rat focal cerebral ischemia model. J. Neurosci. Res. 2010, 88, 1017-1025. [CrossRef] [PubMed]

124. Liu, K.; Ji, K.; Guo, L.; Wu, W.; Lu, H.; Shan, P.; Yan, C. Mesenchymal stem cells rescue injured endothelial cells in an in vitro ischemia-reperfusion model via tunneling nanotube like structure-mediated mitochondrial transfer. Microvasc. Res. 2014, 92, 10-18. [CrossRef] [PubMed] 
125. Song, M.; Mohamad, O.; Gu, X.; Wei, L.; Yu, S.P. Restoration of intracortical and thalamocortical circuits after transplantation of bone marrow mesenchymal stem cells into the ischemic brain of mice. Cell Transplant. 2013, 22, 2001-2015. [CrossRef] [PubMed]

126. Arvidsson, A.; Kokaia, Z.; Lindvall, O. N-methyl-D-aspartate receptor-mediated increase of neurogenesis in adult rat dentate gyrus following stroke. Eur. J. Neurosci. 2001, 14, 10-18. [CrossRef] [PubMed]

127. Parent, J.M.; Vexler, Z.S.; Gong, C.; Derugin, N.; Ferriero, D.M. Rat forebrain neurogenesis and striatal neuron replacement after focal stroke. Ann. Neurol. 2002, 52, 802-813. [CrossRef] [PubMed]

128. Li, Y.; McIntosh, K.; Chen, J.; Zhang, C.; Gao, Q.; Borneman, J.; Raginski, K.; Mitchell, J.; Shen, L.; Zhang, J.; et al. Allogeneic bone marrow stromal cells promote glial-axonal remodeling without immunologic sensitization after stroke in rats. Exp. Neurol. 2006, 198, 313-325. [CrossRef] [PubMed]

129. Liu, Z.; Li, Y.; Zhang, R.L.; Cui, Y.; Chopp, M. Bone marrow stromal cells promote skilled motor recovery and enhance contralesional axonal connections after ischemic stroke in adult mice. Stroke 2011, 42, 740-744. [CrossRef] [PubMed]

130. Van Velthoven, C.T.; van de Looij, Y.; Kavelaars, A.; Zijlstra, J.; van Bel, F.; Huppi, P.S.; Sizonenko, S.; Heijnen, C.J. Mesenchymal stem cells restore cortical rewiring after neonatal ischemia in mice. Ann. Neurol. 2012, 71, 785-796. [CrossRef] [PubMed]

131. Lopez-Verrilli, M.A.; Caviedes, A.; Cabrera, A.; Sandoval, S.; Wyneken, U.; Khoury, M. Mesenchymal stem cell-derived exosomes from different sources selectively promote neuritic outgrowth. Neuroscience 2016, 320, 129-139. [CrossRef] [PubMed]

132. Phinney, D.G.; Pittenger, M.F. Concise Review: MSC-Derived Exosomes for Cell-Free Therapy. Stem Cells 2017, 35, 851-858. [CrossRef] [PubMed]

133. Zhang, Y.; Chopp, M.; Liu, X.S.; Katakowski, M.; Wang, X.; Tian, X.; Wu, D.; Zhang, Z.G. Exosomes Derived from Mesenchymal Stromal Cells Promote Axonal Growth of Cortical Neurons. Mol. Neurobiol. 2017, 54, 2659-2673. [CrossRef] [PubMed]

134. Xin, H.; Li, Y.; Liu, Z.; Wang, X.; Shang, X.; Cui, Y.; Zhang, Z.G.; Chopp, M. MiR-133b promotes neural plasticity and functional recovery after treatment of stroke with multipotent mesenchymal stromal cells in rats via transfer of exosome-enriched extracellular particles. Stem Cells 2013, 31, 2737-2746. [CrossRef] [PubMed]

135. Jin, K.; Mao, X.; Xie, L.; Greenberg, R.B.; Peng, B.; Moore, A.; Greenberg, M.B.; Greenberg, D.A. Delayed transplantation of human neural precursor cells improves outcome from focal cerebral ischemia in aged rats. Aging Cell 2010, 9, 1076-1083. [CrossRef] [PubMed]

136. Biernaskie, J.; Chernenko, G.; Corbett, D. Efficacy of rehabilitative experience declines with time after focal ischemic brain injury. J. Neurosci. 2004, 24, 1245-1254. [CrossRef] [PubMed]

137. Vu, Q.; Xie, K.; Eckert, M.; Zhao, W.; Cramer, S.C. Meta-analysis of preclinical studies of mesenchymal stromal cells for ischemic stroke. Neurology 2014, 82, 1277-1286. [CrossRef] [PubMed]

138. Gutierrez-Fernandez, M.; Rodriguez-Frutos, B.; Alvarez-Grech, J.; Vallejo-Cremades, M.T.; Exposito-Alcaide, M.; Merino, J.; Roda, J.M.; Diez-Tejedor, E. Functional recovery after hematic administration of allogenic mesenchymal stem cells in acute ischemic stroke in rats. Neuroscience 2011, 175, 394-405. [CrossRef] [PubMed]

139. Cui, L.L.; Kerkela, E.; Bakreen, A.; Nitzsche, F.; Andrzejewska, A.; Nowakowski, A.; Janowski, M.; Walczak, P.; Boltze, J.; Lukomska, B.; et al. The cerebral embolism evoked by intra-arterial delivery of allogeneic bone marrow mesenchymal stem cells in rats is related to cell dose and infusion velocity. Stem Cell Res. Ther. 2015, 6, 11. [CrossRef] [PubMed]

140. Ge, J.; Guo, L.; Wang, S.; Zhang, Y.; Cai, T.; Zhao, R.C.; Wu, Y. The size of mesenchymal stem cells is a significant cause of vascular obstructions and stroke. Stem Cell Rev. 2014, 10, 295-303. [CrossRef] [PubMed]

141. Chapman, C.D.; Frey, W.H., 2nd; Craft, S.; Danielyan, L.; Hallschmid, M.; Schioth, H.B.; Benedict, C. Intranasal treatment of central nervous system dysfunction in humans. Pharm. Res. 2013, 30, 2475-2484. [CrossRef] [PubMed]

142. Lochhead, J.J.; Thorne, R.G. Intranasal delivery of biologics to the central nervous system. Adv. Drug Deliv. Rev. 2012, 64, 614-628. [CrossRef] [PubMed]

143. Rodriguez-Frutos, B.; Otero-Ortega, L.; Gutierrez-Fernandez, M.; Fuentes, B.; Ramos-Cejudo, J.; Diez-Tejedor, E. Stem Cell Therapy and Administration Routes After Stroke. Transl. Stroke Res. 2016, 7,378-387. [CrossRef] [PubMed] 
144. Nih, L.R.; Carmichael, S.T.; Segura, T. Hydrogels for brain repair after stroke: An emerging treatment option. Curr. Opin. Biotechnol. 2016, 40, 155-163. [CrossRef] [PubMed]

145. Overman, J.J.; Clarkson, A.N.; Wanner, I.B.; Overman, W.T.; Eckstein, I.; Maguire, J.L.; Dinov, I.D.; Toga, A.W.; Carmichael, S.T. A role for ephrin-A5 in axonal sprouting, recovery, and activity-dependent plasticity after stroke. Proc. Natl. Acad. Sci. USA 2012, 109, E2230-E2239. [CrossRef] [PubMed]

146. Wu, Y.; Wu, J.; Ju, R.; Chen, Z.; Xu, Q. Comparison of intracerebral transplantation effects of different stem cells on rodent stroke models. Cell Biochem. Funct. 2015, 33, 174-182. [CrossRef] [PubMed]

147. Moshayedi, P.; Carmichael, S.T. Hyaluronan, neural stem cells and tissue reconstruction after acute ischemic stroke. Biomatter 2013, 3. [CrossRef] [PubMed]

148. De Keyser, J. Autologous mesenchymal stem cell transplantation in stroke patients. Ann. Neurol. 2005, 58, 653-654. [CrossRef] [PubMed]

149. Bhasin, A.; Srivastava, M.V.; Mohanty, S.; Bhatia, R.; Kumaran, S.S.; Bose, S. Stem cell therapy: A clinical trial of stroke. Clin. Neurol. Neurosurg. 2013, 115, 1003-1008. [CrossRef] [PubMed]

150. Qiao, L.Y.; Huang, F.J.; Zhao, M.; Xie, J.H.; Shi, J.; Wang, J.; Lin, X.Z.; Zuo, H.; Wang, Y.L.; Geng, T.C. A two-year follow-up study of cotransplantation with neural stem/progenitor cells and mesenchymal stromal cells in ischemic stroke patients. Cell Transplant. 2014, 23 (Suppl. 1), S65-S72. [CrossRef] [PubMed]

151. Friedrich, M.A.; Martins, M.P.; Araujo, M.D.; Klamt, C.; Vedolin, L.; Garicochea, B.; Raupp, E.F.; El Ammar, S.J.; Machado, D.C.; Costa, J.C.; et al. Intra-arterial infusion of autologous bone marrow mononuclear cells in patients with moderate to severe middle cerebral artery acute ischemic stroke. Cell Transplant. 2012, 21 (Suppl. 1), S13-S21. [CrossRef] [PubMed]

152. Suarez-Monteagudo, C.; Hernandez-Ramirez, P.; Alvarez-Gonzalez, L.; Garcia-Maeso, I.; de la Cuetara-Bernal, K.; Castillo-Diaz, L.; Bringas-Vega, M.L.; Martinez-Aching, G.; Morales-Chacon, L.M.; Baez-Martin, M.M.; et al. Autologous bone marrow stem cell neurotransplantation in stroke patients. An open study. Restor. Neurol. Neurosci. 2009, 27, 151-161. [CrossRef] [PubMed]

153. Bliss, T.M.; Andres, R.H.; Steinberg, G.K. Optimizing the success of cell transplantation therapy for stroke. Neurobiol. Dis. 2010, 37, 275-283. [CrossRef] [PubMed]

154. Bakshi, A.; Keck, C.A.; Koshkin, V.S.; LeBold, D.G.; Siman, R.; Snyder, E.Y.; McIntosh, T.K. Caspase-mediated cell death predominates following engraftment of neural progenitor cells into traumatically injured rat brain. Brain Res. 2005, 1065, 8-19. [CrossRef] [PubMed]

155. Ballios, B.G.; Cooke, M.J.; Donaldson, L.; Coles, B.L.; Morshead, C.M.; van der Kooy, D.; Shoichet, M.S. A Hyaluronan-Based Injectable Hydrogel Improves the Survival and Integration of Stem Cell Progeny following Transplantation. Stem Cell Reports 2015, 4, 1031-1045. [CrossRef] [PubMed]

156. Bible, E.; Chau, D.Y.; Alexander, M.R.; Price, J.; Shakesheff, K.M.; Modo, M. The support of neural stem cells transplanted into stroke-induced brain cavities by PLGA particles. Biomaterials 2009, 30, 2985-2994. [CrossRef] [PubMed]

157. Dreifus, M.; Wichterle, O.; Lim, D. [Intra-cameral lenses made of hydrocolloidal acrylates]. Cesk. Oftalmol. 1960, 16, 154-159. [PubMed]

158. Wichterle, O.; Lim, D. Hydrophilic Gels for Biological Use. Nature 1960, 185, 117-118. [CrossRef]

159. Pradhan, S.; Clary, J.M.; Seliktar, D.; Lipke, E.A. A three-dimensional spheroidal cancer model based on PEG-fibrinogen hydrogel microspheres. Biomaterials 2017, 115, 141-154. [CrossRef] [PubMed]

160. Sepantafar, M.; Maheronnaghsh, R.; Mohammadi, H.; Rajabi-Zeleti, S.; Annabi, N.; Aghdami, N.; Baharvand, H. Stem cells and injectable hydrogels: Synergistic therapeutics in myocardial repair. Biotechnol. Adv. 2016, 34, 362-379. [CrossRef] [PubMed]

161. Ahmed, E.M. Hydrogel: Preparation, characterization, and applications: A review. J. Adv. Res. 2015, 6, 105-121. [CrossRef] [PubMed]

162. Brown, T.E.; Anseth, K.S. Spatiotemporal hydrogel biomaterials for regenerative medicine. Chem. Soc. Rev. 2017, 46, 6532-6552. [CrossRef] [PubMed]

163. Gulrez, S.K.H.; Al-Assaf, S.; Phillips, G.O. Hydrogels: Methods of Preparation, Characterisation and Applications. In Progress in Molecular and Environmental Bioengineering-From Analysis and Modeling to Technology Applications; Carpi, A., Ed.; InTech: Rijeka, Croatia, 2011; Chapter 5; pp. 117-150. ISBN 978-953-307-268-5.

164. Zabow, G.; Dodd, S.J.; Koretsky, A.P. Shape-changing magnetic assemblies as high-sensitivity NMR-readable nanoprobes. Nature 2015, 520, 73-77. [CrossRef] [PubMed] 
165. Jiang, X.; Georges, P.C.; Li, B.; Du, Y.; Kutzing, M.K.; Previtera, M.L.; Langrana, N.; Firestein, B.L. Cell Growth in Response to Mechanical Stiffness is Affected by Neuron- Astroglia Interactions. Open Neurosci. J. 2007, 107, 7-14. [CrossRef]

166. Lampe, K.J.; Mooney, R.G.; Bjugstad, K.B.; Mahoney, M.J. Effect of macromer weight percent on neural cell growth in 2D and 3D nondegradable PEG hydrogel culture. J. Biomed. Mater. Res. A. 2010, 94, 1162-1171. [CrossRef] [PubMed]

167. Aurand, E.R.; Wagner, J.; Lanning, C.; Bjugstad, K.B. Building biocompatible hydrogels for tissue engineering of the brain and spinal cord. J. Funct. Biomater. 2012, 3, 839-863. [CrossRef] [PubMed]

168. Leach, J.B.; Brown, X.Q.; Jacot, J.G.; Dimilla, P.A.; Wong, J.Y. Neurite outgrowth and branching of PC12 cells on very soft substrates sharply decreases below a threshold of substrate rigidity. J. Neural. Eng. 2007, 4, 26-34. [CrossRef] [PubMed]

169. Murphy, M.C.; Curran, G.L.; Glaser, K.J.; Rossman, P.J.; Huston, J., 3rd; Poduslo, J.F.; Jack, C.R., Jr.; Felmlee, J.P.; Ehman, R.L. Magnetic resonance elastography of the brain in a mouse model of Alzheimer's disease: Initial results. Magn. Reson. Imaging 2012, 30, 535-539. [CrossRef] [PubMed]

170. Tang-Schomer, M.D.; White, J.D.; Tien, L.W.; Schmitt, L.I.; Valentin, T.M.; Graziano, D.J.; Hopkins, A.M.; Omenetto, F.G.; Haydon, P.G.; Kaplan, D.L. Bioengineered functional brain-like cortical tissue. Proc. Natl. Acad. Sci. USA 2014, 111, 13811-13816. [CrossRef] [PubMed]

171. Georges, P.C.; Miller, W.J.; Meaney, D.F.; Sawyer, E.S.; Janmey, P.A. Matrices with compliance comparable to that of brain tissue select neuronal over glial growth in mixed cortical cultures. Biophys. J. 2006, 90, 3012-3018. [CrossRef] [PubMed]

172. Levental, I.; Georges, P.C.; Janmey, P.A. Soft biological materials and their impact on cell function. Soft Matter 2007, 3, 299-306. [CrossRef]

173. Seidlits, S.K.; Khaing, Z.Z.; Petersen, R.R.; Nickels, J.D.; Vanscoy, J.E.; Shear, J.B.; Schmidt, C.E. The effects of hyaluronic acid hydrogels with tunable mechanical properties on neural progenitor cell differentiation. Biomaterials 2010, 31, 3930-3940. [CrossRef] [PubMed]

174. Christ, A.F.; Franze, K.; Gautier, H.; Moshayedi, P.; Fawcett, J.; Franklin, R.J.; Karadottir, R.T.; Guck, J. Mechanical difference between white and gray matter in the rat cerebellum measured by scanning force microscopy. J. Biomech. 2010, 43, 2986-2992. [CrossRef] [PubMed]

175. Anseth, K.S.; Metters, A.T.; Bryant, S.J.; Martens, P.J.; Elisseeff, J.H.; Bowman, C.N. In situ forming degradable networks and their application in tissue engineering and drug delivery. J. Control. Release 2002, 78, 199-209. [CrossRef]

176. Miller, K.; Chinzei, K.; Orssengo, G.; Bednarz, P. Mechanical properties of brain tissue in-vivo: Experiment and computer simulation. J. Biomech. 2000, 33, 1369-1376. [CrossRef]

177. Khaing, Z.Z.; Milman, B.D.; Vanscoy, J.E.; Seidlits, S.K.; Grill, R.J.; Schmidt, C.E. High molecular weight hyaluronic acid limits astrocyte activation and scar formation after spinal cord injury. J. Neural. Eng. 2011, 8, 046033. [CrossRef] [PubMed]

178. Hou, S.; Xu, Q.; Tian, W.; Cui, F.; Cai, Q.; Ma, J.; Lee, I.S. The repair of brain lesion by implantation of hyaluronic acid hydrogels modified with laminin. J. Neurosci. Methods 2005, 148, 60-70. [CrossRef] [PubMed]

179. Lam, J.; Carmichael, S.T.; Lowry, W.E.; Segura, T. Hydrogel design of experiments methodology to optimize hydrogel for iPSC-NPC culture. Adv. Healthc. Mater. 2015, 4, 534-539. [CrossRef] [PubMed]

180. Lam, J.; Lowry, W.E.; Carmichael, S.T.; Segura, T. Delivery of iPS-NPCs to the Stroke Cavity within a Hyaluronic Acid Matrix Promotes the Differentiation of Transplanted Cells. Adv. Funct. Mater. 2014, 24, 7053-7062. [CrossRef] [PubMed]

181. Osanai, T.; Kuroda, S.; Yasuda, H.; Chiba, Y.; Maruichi, K.; Hokari, M.; Sugiyama, T.; Shichinohe, H.; Iwasaki, Y. Noninvasive transplantation of bone marrow stromal cells for ischemic stroke: Preliminary study with a thermoreversible gelation polymer hydrogel. Neurosurgery 2010, 66, 1140-1147. [CrossRef] [PubMed]

182. Gupta, D.; Tator, C.H.; Shoichet, M.S. Fast-gelling injectable blend of hyaluronan and methylcellulose for intrathecal, localized delivery to the injured spinal cord. Biomaterials 2006, 27, 2370-2379. [CrossRef] [PubMed]

183. Nih, L.R.; Sideris, E.; Carmichael, S.T.; Segura, T. Injection of Microporous Annealing Particle (MAP) Hydrogels in the Stroke Cavity Reduces Gliosis and Inflammation and Promotes NPC Migration to the Lesion. Adv. Mater. 2017, 29. [CrossRef] [PubMed] 
184. Somaa, F.A.; Wang, T.Y.; Niclis, J.C.; Bruggeman, K.F.; Kauhausen, J.A.; Guo, H.; McDougall, S.; Williams, R.J.; Nisbet, D.R.; Thompson, L.H.; et al. Peptide-Based Scaffolds Support Human Cortical Progenitor Graft Integration to Reduce Atrophy and Promote Functional Repair in a Model of Stroke. Cell Rep. 2017, 20, 1964-1977. [CrossRef] [PubMed]

185. Park, J.; Lim, E.; Back, S.; Na, H.; Park, Y.; Sun, K. Nerve regeneration following spinal cord injury using matrix metalloproteinase-sensitive, hyaluronic acid-based biomimetic hydrogel scaffold containing brain-derived neurotrophic factor. J. Biomed. Mater. Res. A 2010, 93, 1091-1099. [CrossRef] [PubMed]

186. Massensini, A.R.; Ghuman, H.; Saldin, L.T.; Medberry, C.J.; Keane, T.J.; Nicholls, F.J.; Velankar, S.S.; Badylak, S.F.; Modo, M. Concentration-dependent rheological properties of ECM hydrogel for intracerebral delivery to a stroke cavity. Acta Biomater. 2015, 27, 116-130. [CrossRef] [PubMed]

187. Tseng, T.C.; Tao, L.; Hsieh, F.Y.; Wei, Y.; Chiu, I.M.; Hsu, S.H. An Injectable, Self-Healing Hydrogel to Repair the Central Nervous System. Adv. Mater. 2015, 27, 3518-3524. [CrossRef] [PubMed]

188. Fernandez-Garcia, L.; Mari-Buye, N.; Barios, J.A.; Madurga, R.; Elices, M.; Perez-Rigueiro, J.; Ramos, M.; Guinea, G.V.; Gonzalez-Nieto, D. Safety and tolerability of silk fibroin hydrogels implanted into the mouse brain. Acta Biomater. 2016, 45, 262-275. [CrossRef] [PubMed]

189. Hoffman, A.S. Hydrogels for biomedical applications. Adv. Drug Deliv. Rev. 2002, 54, 3-12. [CrossRef]

190. Yannas, I.V.; Burke, J.F. Design of an artificial skin. I. Basic design principles. J. Biomed. Mater. Res. 1980, 14, 65-81. [CrossRef] [PubMed]

191. Vacanti, J.P.; Morse, M.A.; Saltzman, W.M.; Domb, A.J.; Perez-Atayde, A.; Langer, R. Selective cell transplantation using bioabsorbable artificial polymers as matrices. J. Pediatr. Surg. 1988, 23, 3-9. [CrossRef]

192. Lim, F.; Sun, A.M. Microencapsulated islets as bioartificial endocrine pancreas. Science 1980, 210, 908-910. [CrossRef] [PubMed]

193. Woerly, S.; Laroche, G.; Marchand, R.; Pato, J.; Subr, V.; Ulbrich, K. Intracerebral implantation of hydrogel-coupled adhesion peptides: Tissue reaction. J. Neural. Transplant. Plast. 1995, 5, 245-255. [CrossRef] [PubMed]

194. Woerly, S.; Marchand, R.; Lavallee, C. Intracerebral implantation of synthetic polymer/biopolymer matrix: A new perspective for brain repair. Biomaterials 1990, 11, 97-107. [CrossRef]

195. Lesny, P.; De Croos, J.; Pradny, M.; Vacik, J.; Michalek, J.; Woerly, S.; Sykova, E. Polymer hydrogels usable for nervous tissue repair. J. Chem. Neuroanat. 2002, 23, 243-247. [CrossRef]

196. Sykova, E.; Jendelova, P. In vivo tracking of stem cells in brain and spinal cord injury. Prog. Brain Res. 2007, 161, 367-383. [CrossRef] [PubMed]

197. Pakulska, M.M.; Ballios, B.G.; Shoichet, M.S. Injectable hydrogels for central nervous system therapy. Biomed. Mater. 2012, 7, 024101. [CrossRef] [PubMed]

198. Ju, R.; Wen, Y.; Gou, R.; Wang, Y.; Xu, Q. The experimental therapy on brain ischemia by improvement of local angiogenesis with tissue engineering in the mouse. Cell Transplant. 2014, 23 (Suppl. 1), S83-S95. [CrossRef] [PubMed]

199. Kataoka, K.; Huh, N. Application of a thermo-reversible gelation polymer, mebiol gel, for stem cell culture and regenerative medicine. J. Stem Cells Regen. Med. 2010, 6, 10-14. [PubMed]

200. Payne, S.L.; Anandakumaran, P.N.; Varga, B.V.; Morshead, C.M.; Nagy, A.; Shoichet, M.S. In Vitro Maturation of Human iPSC-Derived Neuroepithelial Cells Influences Transplant Survival in the Stroke-Injured Rat Brain. Tissue Eng. Part A 2017, 24. [CrossRef]

201. Sun, W.; Incitti, T.; Migliaresi, C.; Quattrone, A.; Casarosa, S.; Motta, A. Viability and neuronal differentiation of neural stem cells encapsulated in silk fibroin hydrogel functionalized with an IKVAV peptide. J. Tissue Eng. Regen. Med. 2017, 11, 1532-1541. [CrossRef] [PubMed]

202. Thonhoff, J.R.; Lou, D.I.; Jordan, P.M.; Zhao, X.; Wu, P. Compatibility of human fetal neural stem cells with hydrogel biomaterials in vitro. Brain Res. 2008, 1187, 42-51. [CrossRef] [PubMed]

203. Wang, Z.; Wang, J.; Jin, Y.; Luo, Z.; Yang, W.; Xie, H.; Huang, K.; Wang, L. A Neuroprotective Sericin Hydrogel As an Effective Neuronal Cell Carrier for the Repair of Ischemic Stroke. ACS Appl. Mater. Interfaces 2015, 7, 24629-24640. [CrossRef] [PubMed]

204. Park, K.I.; Teng, Y.D.; Snyder, E.Y. The injured brain interacts reciprocally with neural stem cells supported by scaffolds to reconstitute lost tissue. Nat. Biotechnol. 2002, 20, 1111-1117. [CrossRef] [PubMed] 
205. Caicco, M.J.; Cooke, M.J.; Wang, Y.; Tuladhar, A.; Morshead, C.M.; Shoichet, M.S. A hydrogel composite system for sustained epi-cortical delivery of Cyclosporin A to the brain for treatment of stroke. J. Control. Release. 2013, 166, 197-202. [CrossRef] [PubMed]

206. Cook, D.J.; Nguyen, C.; Chun, H.N.; Llorente, I.L.; Chiu, A.S.; Machnicki, M.; Zarembinski, T.I.; Carmichael, S.T. Hydrogel-delivered brain-derived neurotrophic factor promotes tissue repair and recovery after stroke. J. Cereb. Blood Flow MeTable 2017, 37, 1030-1045. [CrossRef] [PubMed]

207. Emerich, D.F.; Silva, E.; Ali, O.; Mooney, D.; Bell, W.; Yu, S.J.; Kaneko, Y.; Borlongan, C. Injectable VEGF hydrogels produce near complete neurological and anatomical protection following cerebral ischemia in rats. Cell Transplant. 2010, 19, 1063-1071. [CrossRef] [PubMed]

208. Ma, J.; Tian, W.M.; Hou, S.P.; Xu, Q.Y.; Spector, M.; Cui, F.Z. An experimental test of stroke recovery by implanting a hyaluronic acid hydrogel carrying a Nogo receptor antibody in a rat model. Biomed. Mater. 2007, 2, 233-240. [CrossRef] [PubMed]

209. Wang, Y.; Cooke, M.J.; Morshead, C.M.; Shoichet, M.S. Hydrogel delivery of erythropoietin to the brain for endogenous stem cell stimulation after stroke injury. Biomaterials 2012, 33, 2681-2692. [CrossRef] [PubMed]

210. Hoban, D.B.; Newland, B.; Moloney, T.C.; Howard, L.; Pandit, A.; Dowd, E. The reduction in immunogenicity of neurotrophin overexpressing stem cells after intra-striatal transplantation by encapsulation in an in situ gelling collagen hydrogel. Biomaterials 2013, 34, 9420-9429. [CrossRef] [PubMed]

211. Jendelova, P.; Kubinova, S.; Sandvig, I.; Erceg, S.; Sandvig, A.; Sykova, E. Current developments in cell- and biomaterial-based approaches for stroke repair. Expert Opin. Biol. Ther. 2016, 16, 43-56. [CrossRef] [PubMed]

212. Chaudhuri, O.; Gu, L.; Klumpers, D.; Darnell, M.; Bencherif, S.A.; Weaver, J.C.; Huebsch, N.; Lee, H.P.; Lippens, E.; Duda, G.N.; et al. Hydrogels with tunable stress relaxation regulate stem cell fate and activity. Nat. Mater. 2016, 15, 326-334. [CrossRef] [PubMed]

213. Gilbert, P.M.; Havenstrite, K.L.; Magnusson, K.E.; Sacco, A.; Leonardi, N.A.; Kraft, P.; Nguyen, N.K.; Thrun, S.; Lutolf, M.P.; Blau, H.M. Substrate elasticity regulates skeletal muscle stem cell self-renewal in culture. Science 2010, 329, 1078-1081. [CrossRef] [PubMed]

214. Madl, C.M.; LeSavage, B.L.; Dewi, R.E.; Dinh, C.B.; Stowers, R.S.; Khariton, M.; Lampe, K.J.; Nguyen, D.; Chaudhuri, O.; Enejder, A.; et al. Maintenance of neural progenitor cell stemness in 3D hydrogels requires matrix remodelling. Nat. Mater. 2017, 16, 1233-1242. [CrossRef] [PubMed]

215. Wang, T.W.; Spector, M. Development of hyaluronic acid-based scaffolds for brain tissue engineering. Acta Biomater. 2009, 5, 2371-2384. [CrossRef] [PubMed]

216. Khetan, S.; Burdick, J. Cellular encapsulation in 3D hydrogels for tissue engineering. J. Vis. Exp. 2009, 32, 1590. [CrossRef] [PubMed]

217. Wang, X.; Kluge, J.A.; Leisk, G.G.; Kaplan, D.L. Sonication-induced gelation of silk fibroin for cell encapsulation. Biomaterials 2008, 29, 1054-1064. [CrossRef] [PubMed]

218. Schlosshauer, B.; Muller, E.; Schroder, B.; Planck, H.; Muller, H.W. Rat Schwann cells in bioresorbable nerve guides to promote and accelerate axonal regeneration. Brain Res. 2003, 963, 321-326. [CrossRef]

219. Peppas, N.A.; Khademhosseini, A. Make better, safer biomaterials. Nature 2016, 540, 335-337. [CrossRef] [PubMed]

220. Boisserand, L.S.; Kodama, T.; Papassin, J.; Auzely, R.; Moisan, A.; Rome, C.; Detante, O. Biomaterial Applications in Cell-Based Therapy in Experimental Stroke. Stem Cells Int. 2016, 2016, 6810562. [CrossRef] [PubMed]

221. Dalton, P.D.; Mey, J. Neural interactions with materials. Front Biosci (Landmark Ed.) 2009, 14, 769-795. [CrossRef] [PubMed]

222. Potter, W.; Kalil, R.E.; Kao, W.J. Biomimetic material systems for neural progenitor cell-based therapy. Front. Biosci. 2008, 13, 806-821. [CrossRef] [PubMed]

223. Clark, A.R.; Carter, A.B.; Hager, L.E.; Price, E.M. In Vivo Neural Tissue Engineering: Cylindrical Biocompatible Hydrogels That Create New Neural Tracts in the Adult Mammalian Brain. Stem Cells Dev. 2016, 25, 1109-1118. [CrossRef] [PubMed]

224. Ghuman, H.; Massensini, A.R.; Donnelly, J.; Kim, S.M.; Medberry, C.J.; Badylak, S.F.; Modo, M. ECM hydrogel for the treatment of stroke: Characterization of the host cell infiltrate. Biomaterials 2016, 91, 166-181. [CrossRef] [PubMed]

225. Cui, F.Z.; Tian, W.M.; Hou, S.P.; Xu, Q.Y.; Lee, I.S. Hyaluronic acid hydrogel immobilized with RGD peptides for brain tissue engineering. J. Mater. Sci. Mater. Med. 2006, 17, 1393-1401. [CrossRef] [PubMed] 
226. Borlongan, C.V.; Skinner, S.J.; Geaney, M.; Vasconcellos, A.V.; Elliott, R.B.; Emerich, D.F. Intracerebral transplantation of porcine choroid plexus provides structural and functional neuroprotection in a rodent model of stroke. Stroke 2004, 35, 2206-2210. [CrossRef] [PubMed]

227. Lampe, K.J.; Kern, D.S.; Mahoney, M.J.; Bjugstad, K.B. The administration of BDNF and GDNF to the brain via PLGA microparticles patterned within a degradable PEG-based hydrogel: Protein distribution and the glial response. J. Biomed. Mater. Res. A 2011, 96, 595-607. [CrossRef] [PubMed]

228. Deguchi, K.; Tsuru, K.; Hayashi, T.; Takaishi, M.; Nagahara, M.; Nagotani, S.; Sehara, Y.; Jin, G.; Zhang, H.; Hayakawa, S.; et al. Implantation of a new porous gelatin-siloxane hybrid into a brain lesion as a potential scaffold for tissue regeneration. J. Cereb. Blood Flow MeTable 2006, 26, 1263-1273. [CrossRef] [PubMed]

229. Yu, H.; Cao, B.; Feng, M.; Zhou, Q.; Sun, X.; Wu, S.; Jin, S.; Liu, H.; Lianhong, J. Combinated transplantation of neural stem cells and collagen type I promote functional recovery after cerebral ischemia in rats. Anat. Rec. (Hoboken) 2010, 293, 911-917. [CrossRef] [PubMed]

230. Bible, E.; Qutachi, O.; Chau, D.Y.; Alexander, M.R.; Shakesheff, K.M.; Modo, M. Neo-vascularization of the stroke cavity by implantation of human neural stem cells on VEGF-releasing PLGA microparticles. Biomaterials 2012, 33, 7435-7446. [CrossRef] [PubMed]

231. Ito, M.; Shichinohe, H.; Houkin, K.; Kuroda, S. Application of cell sheet technology to bone marrow stromal cell transplantation for rat brain infarct. J. Tissue Eng. Regen. Med. 2017, 11, 375-381. [CrossRef] [PubMed]

232. Moshayedi, P.; Nih, L.R.; Llorente, I.L.; Berg, A.R.; Cinkornpumin, J.; Lowry, W.E.; Segura, T.; Carmichael, S.T. Systematic optimization of an engineered hydrogel allows for selective control of human neural stem cell survival and differentiation after transplantation in the stroke brain. Biomaterials 2016, 105, 145-155. [CrossRef] [PubMed]

233. Zhong, J.; Chan, A.; Morad, L.; Kornblum, H.I.; Fan, G.; Carmichael, S.T. Hydrogel matrix to support stem cell survival after brain transplantation in stroke. Neurorehabil. Neural Repair 2010, 24, 636-644. [CrossRef] [PubMed]

234. Tashiro, K.; Sephel, G.C.; Weeks, B.; Sasaki, M.; Martin, G.R.; Kleinman, H.K.; Yamada, Y. A synthetic peptide containing the IKVAV sequence from the A chain of laminin mediates cell attachment, migration, and neurite outgrowth. J. Biol. Chem. 1989, 264, 16174-16182. [PubMed]

235. Ghuman, H.; Gerwig, M.; Nicholls, F.J.; Liu, J.R.; Donnelly, J.; Badylak, S.F.; Modo, M. Long-term retention of ECM hydrogel after implantation into a sub-acute stroke cavity reduces lesion volume. Acta Biomater. 2017, 63, 50-63. [CrossRef] [PubMed]

236. Guan, J.; Zhu, Z.; Zhao, R.C.; Xiao, Z.; Wu, C.; Han, Q.; Chen, L.; Tong, W.; Zhang, J.; Gao, J.; et al. Transplantation of human mesenchymal stem cells loaded on collagen scaffolds for the treatment of traumatic brain injury in rats. Biomaterials 2013, 34, 5937-5946. [CrossRef] [PubMed]

237. Tate, C.C.; Shear, D.A.; Tate, M.C.; Archer, D.R.; Stein, D.G.; LaPlaca, M.C. Laminin and fibronectin scaffolds enhance neural stem cell transplantation into the injured brain. J. Tissue Eng. Regen. Med. 2009, 3, $208-217$. [CrossRef] [PubMed]

238. Phng, L.K.; Gerhardt, H. Angiogenesis: A team effort coordinated by notch. Dev. Cell 2009, 16, $196-208$. [CrossRef] [PubMed]

239. Nakaguchi, K.; Jinnou, H.; Kaneko, N.; Sawada, M.; Hikita, T.; Saitoh, S.; Tabata, Y.; Sawamoto, K. Growth factors released from gelatin hydrogel microspheres increase new neurons in the adult mouse brain. Stem Cells Int. 2012, 2012, 915160. [CrossRef] [PubMed]

240. Taylor, S.J.; Rosenzweig, E.S.; McDonald, J.W., 3rd; Sakiyama-Elbert, S.E. Delivery of neurotrophin-3 from fibrin enhances neuronal fiber sprouting after spinal cord injury. J. Control. Release 2006, 113, $226-235$. [CrossRef] [PubMed]

241. Tesar, B.M.; Jiang, D.; Liang, J.; Palmer, S.M.; Noble, P.W.; Goldstein, D.R. The role of hyaluronan degradation products as innate alloimmune agonists. Am. J. Transplant. 2006, 6, 2622-2635. [CrossRef] [PubMed]

242. Back, S.A.; Tuohy, T.M.; Chen, H.; Wallingford, N.; Craig, A.; Struve, J.; Luo, N.L.; Banine, F.; Liu, Y.; Chang, A.; et al. Hyaluronan accumulates in demyelinated lesions and inhibits oligodendrocyte progenitor maturation. Nat. Med. 2005, 11, 966-972. [CrossRef] [PubMed]

243. Cargill, R.; Kohama, S.G.; Struve, J.; Su, W.; Banine, F.; Witkowski, E.; Back, S.A.; Sherman, L.S. Astrocytes in aged nonhuman primate brain gray matter synthesize excess hyaluronan. Neurobiol. Aging 2012, 33, 830.e13-830.e24. [CrossRef] [PubMed] 
244. Nicholas, A.P.; McInnis, C.; Gupta, K.B.; Snow, W.W.; Love, D.F.; Mason, D.W.; Ferrell, T.M.; Staas, J.K.; Tice, T.R. The fate of biodegradable microspheres injected into rat brain. Neurosci. Lett. 2002, 323, 85-88. [CrossRef]

245. Skop, N.B.; Calderon, F.; Cho, C.H.; Gandhi, C.D.; Levison, S.W. Improvements in biomaterial matrices for neural precursor cell transplantation. Mol. Cell. Ther. 2014, 2, 19. [CrossRef] [PubMed]

246. Tsai, C.Y.; Woung, L.C.; Yen, J.C.; Tseng, P.C.; Chiou, S.H.; Sung, Y.J.; Liu, K.T.; Cheng, Y.H. Thermosensitive chitosan-based hydrogels for sustained release of ferulic acid on corneal wound healing. Carbohydr. Polym. 2016, 135, 308-315. [CrossRef] [PubMed]

247. Hofmann, S.; Foo, C.T.; Rossetti, F.; Textor, M.; Vunjak-Novakovic, G.; Kaplan, D.L.; Merkle, H.P.; Meinel, L. Silk fibroin as an organic polymer for controlled drug delivery. J. Control. Release 2006, 111, $219-227$. [CrossRef] [PubMed]

248. Thurber, A.E.; Omenetto, F.G.; Kaplan, D.L. In vivo bioresponses to silk proteins. Biomaterials 2015, 71, 145-157. [CrossRef] [PubMed]

249. Fernández-García, L.; Pérez-Rigueiro, J.; Martinez-Murillo, R.; Panetsos, F.; Ramos, M.; Guinea, G.V.; González-Nieto, D. (Center for Biomedical Technology, Madrid, Spain). Personal Communication, 2017.

250. Flanagan, L.A.; Rebaza, L.M.; Derzic, S.; Schwartz, P.H.; Monuki, E.S. Regulation of human neural precursor cells by laminin and integrins. J. Neurosci. Res. 2006, 83, 845-856. [CrossRef] [PubMed]

251. Aurand, E.R.; Wagner, J.L.; Shandas, R.; Bjugstad, K.B. Hydrogel formulation determines cell fate of fetal and adult neural progenitor cells. Stem Cell Res. 2014, 12, 11-23. [CrossRef] [PubMed]

(C) 2018 by the authors. Licensee MDPI, Basel, Switzerland. This article is an open access article distributed under the terms and conditions of the Creative Commons Attribution (CC BY) license (http:/ / creativecommons.org/licenses/by/4.0/). 